\title{
Özel ile Kamusal Ekseninde Covid-19 Pandemisi: Cinsiyetlendirilmiş Gündelik Kentsel Mekân Deneyimi ve Kadınların Güvenlik Mesaisi ${ }^{1}$
}

\author{
Selda Tuncer ${ }^{2}$ \\ ORCID: 0000-0002-4657-6334
}

\author{
Rabia Demirci ${ }^{3}$ \\ ORCID: 0000-0001-8423-1495
}

\section{Öz}

Türkiye'de 10 Mart 2020 tarihinde ilk koronavirüs vakasının açıklanmasıyla birlikte salgını önlemeye yönelik uygulanan kısıtlama ve yasaklar, gündelik hayatın özel-kamusal ikiliğine dayalı toplumsal ve mekânsal örgütlenmesini temelden sarsarak yeni bir "normal" ortaya çıkarmıştır. Covid-19 pandemisiyle birlikte sosyal etkileşimlerin ve mekânsal pratiklerin son derece kısıtlanması, maske takma zorunluluğu ve diğer sosyal mesafe kuralları kamusal mekânların kullanımına yönelik yeni normlar üreterek insanların bu mekânlarla ilişkilerini ve onlara yükledikleri anlamları derinden etkilemiştir. Türkiye'de özel ile kamusal arasındaki sınırların hala son derece cinsiyetlendirilmiş pratiklere bağh olarak düzenleniyor olmasl, salgin sürecinde kamusal mekânın uğradiğı bu dönüşümün toplumsal cinsiyet açısından da önemli sonuçlar doğurmasına yol açmıştır. Bu çalışmanın amacl, pandeminin etkileri tartışılırken genelde ihmal edilen toplumsal cinsiyet ve mekân ilişkisi perspektifinden, salgında gündelik kamusal mekân kullanım ve deneyimlerinin ne tür değişimlere uğradığını ortaya çıkarmaktır. Bu doğrultuda twitter özelinde sosyal medya incelemesi ve gazete haber taramasından elde edilen veriler ışığında, salgın tedbirleri kapsamında kamusal mekânların ve faaliyetlerin kısıtlanmasının kadınlar ve erkeklerin sosyo-mekânsal pratikleri üzerinde nasıl farkl sonuçları olduğunun incelenmesi hedeflenmiştir. Buna bağh olarak, twitter incelemesinin sonuçlarından hareketle, kadınların pandemide karşılaştığ 1 cinsel taciz ve şiddet olaylarının ev çevresinden kent kamusal mekânlarına farklı ölçeklerde nasıl ortaya çıktı̆̆ı ve bu bağlamda kadınların salgınla birlikte değişen güvenlik mesaileri ele alınmıştır.

Anahtar Kelimeler: Covid-19, kamusal mekân, toplumsal cinsiyet, erkek şiddeti, kent hakkı

\footnotetext{
${ }^{1} \mathrm{Bu}$ makale Swedish Institute in Istanbul (SRII) tarafından desteklenmiş olan "Women"s Changing Spatial Experiences and Gendered Violence in Turkey and Sweden during the Covid-19 Pandemic" başlıklı proje kapsamında yürütmüş olduğumuz araştırmaya dayanmaktadır.

${ }^{2}$ Dr. Öğr. Üyesi, Van Yüzüncü Yıl Üniversitesi, E-mail: seldatuncer@yyu.edu.tr

${ }^{3}$ Yüksek Lisans Mezunu, Marmara Üniversitesi, E-mail: rabiadeemirci@gmail.com

idealkent @ Kent Araştırmaları Dergisi (Journal of Urban Studies)

http://idealkentdergisi.com
}

Geliş Tarihi Received Date: 08.03.2021 Kabul Tarihi Accepted Date: 07.09.2021 


\title{
Covid-19 Pandemic Across the Public-Private Division: Gendered Everyday Urban Experience and Women's Safety Work
}

\author{
Selda Tuncer ${ }^{4}$ \\ ORCID: 0000-0001-5367-4373
}

\author{
Rabia Demirci ${ }^{5}$ \\ ORCID: 0000-0001-8423-1495
}

\begin{abstract}
The Covid-19 crisis led to a new "normal," shaking the socio-spatial organization based on the private-public binary of the daily life to its foundations. With the pandemic, the extreme restrictions put on social interactions and spatial practices, the obligation to wear masks and other social distance rules have created new norms for the use of public spaces, deeply affecting the relationships of people with these spaces and the meanings they attribute to them. The fact that the boundaries between the private and public in Turkey have still been regulated based on highly gendered practices have led the transformation of the public space during the epidemic to have a significant impact in terms of gender. The aim of this study, while discussing the effects of the pandemic from the perspective of the relationship between gender and space, which is generally neglected, will be to explore how everyday public space experiences have changed during the epidemic. For this purpose, in the light of the data obtained from social media (twitter) and newspapers, it is aimed to examine how the restriction of public spaces and activities within the scope of lockdown measures have different consequences on the socio-spatial practices of women and men.
\end{abstract}

Keywords: Covid-19, public space, gender, male violence, a right to the city

${ }^{4}$ Dr. Öğr. Üyesi, Van Yüzüncü Yıl Üniversitesi, E-mail: seldatuncer@yyu.edu.tr

${ }^{5}$ Yüksek Lisans Mezunu, Marmara Üniversitesi, E-mail: rabiadeemirci@gmail.com

idealkent (c) Kent Araştırmaları Dergisi (Journal of Urban Studies)

http://idealkentdergisi.com

Geliş Tarihi Received Date: 08.03.2021 Kabul Tarihi Accepted Date: 07.09.2021 


\section{Giriş: Pandeminin Etkilerine Toplumsal Cinsiyet ve Mekân Ekseninden Bakmak}

2019'un sonunda Çin'in Wuhan bölgesinin başkenti Hubei'de ortaya çıkan Covid-19 virüsü dünya çapında hızla yayılarak küresel bir salgına dönüşmüştür. En temelde bir sağlık sorunu olarak ortaya çıkmakla birlikte, koronavirüs salgını bütün dünyada toplumları her yönüyle derinlemesine etkileyen sonuçları bakımından küresel bir toplumsal krize dönüşmüş olup, bu nedenle "topyekün bir toplumsal olgu" (Mauss, 2009) olarak tanımlanmıştır (Alteri, Parks, Raffini, ve Vitale, 2020; Corlianò, 2020; Demertzis ve Eyerman, 2020; Gius, 2020). Dünyanın farklı ülkelerinde bölgesel, ulusal ve uluslararası ölçeklerde yapısal eşitsizliklere bağlı olarak sosyo-ekonomik ve politik açıdan farklı etkiler doğuran bu krizin en önemli sonuçlarından biri ise, toplumsal hayatı belirleyen ve sürdüren olağan yaşama pratiklerinin ve alışkanlıklarının temelden sarsıntıya uğramasıdır. Bu anlamda, Covid-19 kirizinin toplumsal bir olgu olarak bütünselliği, en çok da bildiğimiz dünya düzenini makro düzeyden gündelik hayata uzanan bir değişimle kesintiye uğratmasına dayanır. Virüsün yayılmasını engellemek için evde kalma, sokağa çıkma yasağ1 ve karantina gibi yerelden küresele farklı düzeylerde uygulanan önleyici tedbir ve kısıtlamalar bugüne dek süregelen 'normal' alışkanlığın ve gündelik rutinin bozulmasına yol açtığı gibi, bu durumun bir yıldan fazla süredir devam etmesiyle adeta yeni bir 'normal' ortaya çıarmıştır. Salgının dayattığı bu yeni 'normal' in temelinde ise, modern toplumsal hayatın örgütlenişinde kilit rol oynayan içerisi ile dışarısı, özel ile kamusal arasındaki geleneksel sınurların çözülerek tersyüz edilmesi yatar.

Devlet ve yerel yönetimlerce hayata geçirilen evde kalmaya yönelik yasaklar ve kısıtlayıcı uygulamaların yanı sıra, insanların salgından korunmak için sosyo-mekânsal davranışlarını değiştirmeleri, evlerin geleneksel kullanımını yerle bir ederken kamusal mekânların işlev ve anlamlarının yeniden tanımlanmasına yol açmıştır. Özellikle eğitim ve çalışma başta olmak üzere d1şarı faaliyetlerinin ev içine taşınmasıyla ev mekânları son derece kamusallaşmış olup, buna karşın sokaklar, parklar ya da restoran, kafe, alışveriş merkezi gibi insanların sosyalleştiği ticari işletmeler uzak durulması gereken riskli yerler haline gelmiştir. Bunun sonucunda, çoğunlukla mahremiyet ve sığınak yeri olarak görülen evler dışarısı tarafından işgal edilirken, sosyal mesafenin yeni norm olduğu kamusal mekânların ıssızlaşmasıyla bugüne dek insanların sahip olduğu mekân ve yer duygusunda büyük bir sarsılma olmuştur 
(Devine-Wright vd., 2020). Özetle, içerisi ile dışarısı, özel ile kamusal arasındaki alışlagelmiş dengeler altüst olmuştur. Bu anlamda, Iranmanesh ve Atun'un (2020) son derece yerinde tespitiyle, "covid-19 salgın sosyal etkileşimlerin mekânsal biçimlerinin değişime tabi olduğu bir anı temsil etmektedir." Salgının yol açtı̆̆ karantina uygulamaları ve sosyo-mekansal kısıtlamalar, mekanın toplumsal hayatın oluşumunda ve sürdürülmesinde belirleyici bir role sahip olduğunu gözler önüne sermiştir.

Koronavirüs pandemisi üzerine yazdıkları değerlendirmede DevineWright vd. (2020), mevcut salgın koşullarının insanların mekân ve yerle ilişkilerinin ayrılmaz parçası olan üç temel kuramsal diyalektiği ön plana çıkardığını ileri sürer: yerleş(tir)me-yerinden edilme, içeri-dışarı ve sabitlik-akış. Özel ile kamusal arasındaki sınırların da belirlenmesinde merkezi rol oynayan bu üçlü diyalektik, bu çalışmanın ana odağını oluşturan salgında kamusal mekân deneyiminin geçirdiği dönüşüme ilişkin önemli bir içgörü sağlarken, aynı zamanda insanların mekân ve yerle ilişkilerinin eşitsizlik ve çatı̧ma gibi süreçleri barındıran politik boyutunu anlama imkânı sunar. Çünkü mekân, iktidar ilişkileriyle tamamen iç içe geçmiş ve onların bir ürünü olduğu gibi, iktidarın da bir mekânsallığı ve coğrafyası vardır (Massey, 2009). Covid-19 salgınıyla birlikte değişen toplumsal hayatın düzenlenmesinde; d1şarıdan içeriye, hareketlilik ve akıştan sabitliğe geçiş ve bunlara paralel olarak kamusal mekânların zorunlu olarak terk edilerek evlere yerleşme eğilimi hâkim olmuştur. Ancak yoksulluk ve eşitsizliğin iyice derinleştiği pandemi döneminde, sığınıp yerleşecek bir eve sahip olmak ya da işyerindeki çalışma hayatını eve taşımak herkes için geçerli olmadığı gibi adeta bir lüks haline gelmiştir. Dünyanın her yerinde salgın önleyici tedbirler kapsamında boşalan sokakları ve toplu taşıma araçlarını, çalışmak zorunda olan düşük gelir gruplarından kimseler ve özellikle de sağlık, bakım, güvenlik ya da gıda gibi kilit sektörlerde çalışanlar doldurmaktadır (van Dorn, Cooney ve Sabin, 2020; Valentino-DeVries, Lu, ve Dance 2020). Ayrıca, bu zorunlulukların dışında, salgında sosyo-mekânsal kısıtlamalar el verdiği ölçüde yürüyüş ve spor yapmak gibi faaliyetler amaciyla kamusal mekânların kullanımında da farklı toplumsal gruplar arasında büyük eşitsizlikler gün yüzüne çımıştır. Dolayısıyla Covid-19 pandemisi erişim, dışlanma ve yerinden edilme etrafında gelişen mevcut toplumsal ve mekânsal eşitsizlikleri arttırırken, kamusal alanda ırk, milliyet ve cinsiyet gibi farklılara bağlı ayrımcılıkları da Low ve Smart'ın (2020) deyiş̧iyle "medikalleştirilmiş" bir formda yeniden üreterek beslemektedir. 
Salgınla birlikte uygulanan tedbir kısıtlamaları etkileşimleri en aza indirerek kamusal hayatı sınırlamaya çalışırken, maske takma zorunluluğu ve diğer sosyal mesafe kuralları ise günlük kamusal mekânların kullanımına dair yeni toplumsal normlar üreterek insanların bu mekânlarla ilişkilerini ve onlara yükledikleri anlamları derinden etkilemiştir. Ayrıca, dışarıyla ve kamusal hayatla etkileşimlerin kısıtlanması ve hatta engellenmesi kontrol edilemeyen virüsün bulaşma riski nedeniyle kamusal mekânları tehlikeli ve uzak durulması gereken yerler haline getirmiştir. Pandemi sürecinde kamusal mekânı ciddi bir dönüşüme uğratan tüm bu değişimlerin kentsel mekân ve yaşam üzerindeki etkileri büyük önem taşımaktadır çünkü kamusal mekânın erişilebilirliği ve kullanımı, temel ihtiyaçların karşılanmasıyla birlikte kaynak ve hizmetlere erişimle yakından ilgili olduğu için kent hakkını doğrudan etkilemektedir (Mitchell, 2003). 2000'li yıllardan başlayarak Lefebvre'in "kent hakkı" kavramı etrafında gelişen tartışmalar, Covid-19 sonrası kentlerin ve kentsel mekânların geleceğinin nasıl şekilleneceği ve daha yaşanabilir, sağlıklı ve güvenli kentler için ne gibi çözüm önerileri getirilebileceği üzerine sorgulamalarla yeniden canlanmıştır. Ancak bu konular hakkında yayınlanan rapor ve değerlendirmelerin genelinde, salgınla birlikte derinleşen kentsel eşitsizlik ve yoksulluğa sınıf ve irk bağlamında dikkat çekilmesine rağmen, toplumsal cinsiyet boyutunun belirli konularla sinurlı tutulduğu ve özellikle kent kamusal mekânları üzerine tartışmalarda ciddi biçimde ihmal edildiği gözlenmektedir.

Pandeminin toplumsal cinsiyete bağlı etkileri ağırlıklı olarak kadınların özel alanda yaşadıkları ve özellikle de ev içi şiddet bağlamında ele alınmaktadır. Şüphesiz Covid-19 ortaya çıkmadan önce de her yıl tüm dünyada milyonlarca kadın ve kız çocuğunun zarar görmesiyle adeta bir pandemiye dönüşmüş olan toplumsal cinsiyet temelli şiddetin (Bows ve Fileborn, 2020), k1sitlama ve karantina önlemleriyle kapanılan evlerde dehşet verici düzeyde artışını düşünürsek bu durum şaşırtıcı değildir (Azcona vd., 2020). Hatta, Birleşmiş Milletler (BM) Kadın Birimi'nin (2020a) "gölge pandemi" ilan ettiği ev içi şiddet olgusunun kentlerin geleceğine ilişkin tartı̧̧malarda yer verilmesi umut vericidir. Zira feminist eleştirilerin sıklıkla vurguladığı üzere, "kent hakkı" kavramı özel-kamusal ayrımının cinsiyetlendirilmiş yapısını sorunsallaştırmayarak özel alanı dışarıda bırakmaktadır (Fenster, 2005; Sadri, 2011). Buna karşın, kent hakkıyla özdeşleştirilen kamusal mekânın toplumsal cinsiyet açısından nötr olarak görülme eğiliminin pandemi sürecindeki kent tartışmalarında da sürdürüldüğü gözlenmektedir. Oysaki tasarlanmasından kullanımına kadar kent kamusal mekânlarının üretimi, sınıf ve ırka bağlı olarak şekillendiği gibi, aynı zamanda son derece cinsiyetlendirilmiş norm ve 
pratiklere dayanır. Salgın kontrol tedbirleriyle uygulanan sosyo-mekânsal k1sttlamalar özel ile kamusal arasındaki geleneksel sınırların çözülmesine yol açmışsa da, özel-kamusal ayrımını besleyen cinsiyetlendirilmiş pratiklerin istikrarını bozmadığı gibi aksine daha da beslemiştir (Parvathi, 2020). BM Kadın Birimi'nin (2020b) Covid-19 pandemisi sürecinde kentlerde ve kamusal mekânlarda kadınlar ve kız çocuklarının güvenliğine ilişkin yayınladığı değerlendirmede; salgın boyunca günlük kamusal mekânlarda kadınlara yönelik cinsel şiddet ve diğer şiddet türlerinin görülmeye devam ettiğine yer verilirken, dışarıdaki insan sayısının azalması nedeniyle cinsel şiddet riskinin daha da arttığına dikkat çekilmiştir. Polis, medya ve sivil toplum kuruluşlarından elde edilen veriler, pandemide kadınların sokakta yürürken, parkta spor yaparken veya toplu taşımayla işe giderken (özellikle temel hizmetler ve enformel sektörde çalışanlar) sıklıkla cinsel taciz ve şiddet riskiyle karşı karşıya kaldıklarını ortaya koymuştur (BM Kadın, 2020b). Sonuç olarak kadınlar Covid-19 krizinde, salgının yol açtığı diğer birçok sorunun yanı sıra, özelden kamusal alana, ev içlerinden sokaklara uzanan toplumsal cinsiyet temelli şiddetin çeşitli türleriyle baş etmek durumunda kalmıştır.

Bu çalışmada, kamu sağlığını koruma amacıyla özel ile kamusal arasındaki sınırların yasaklar ve kısıtlamalar doğrultusunda yeniden düzenlenmesini zorunlu kılan Covid-19 pandemisinin Türkiye örneğinde kamusal mekân ve kamusal yaşamı nasıl etkilediğini toplumsal cinsiyet perspektifinden ele almayı amaçliyoruz. Bunun için öncelikle, sosyal medya ve gazete haberlerinden elde edilen verilere dayanarak, hem hükümet hem de yerel yönetimlerin uygulamaları doğrultusunda kamusal mekânların ve faaliyetlerin kısıtlanmasının toplumsal cinsiyet rolleri ve pratikleri açısından ne tür sonuçlar doğurduğunu inceleyeceğiz. Bunun ardından, toplumsal cinsiyet temelli şiddetin özel alandan kamusal alana süreklilik gösterdiği argümanından (Kelly, 1987) hareketle, pandemi sürecinde cinsel taciz ve şiddetin ev çevresinden kent kamusal mekânlarına farklı ölçeklerde nasıl ortaya çıktığını, kadınların sosyal medyada paylaştıkları gündelik deneyimleri aracılığıyla takip edeceğiz. Bunların ışı̆̆ında, cinsiyetlendirilmiş bir alan olarak kamusal mekânın küresel bir salgın krizi bağlamında gündelik hayatta nasıl bir değişime uğradığını ve bu değişimin kadınların kentsel mekân deneyimleri ve kamusal hayata katılımları açısından ne tür olumsuz sonuçlar doğurduğunu kent hakkı ekseninde tartışmaya açacağız. 


\section{Kamusal Mekân ve Toplumsal Cinsiyet Bağlamında Kadınların Kent Hakkı}

Lefebvre'nin (1991 [1973]) modern kapitalist kent hayatında mekân dâhil her şeyin metalaşmasıyla oluşan sınıfsal eşitsizlikler ve ayrışmalar üzerinden tanımladı̆̆ı "kent hakkı" kavramı, kent sakinlerinin yaşadıkları kentin mekânlarına erişebilme ve onları kullanma haklarıyla birlikte aynı zamanda kent mekânını ihtiyaçlarına göre değiştirme, dahası bunun için örgütlenme hakkını kapsar. Dolayısıyla kent hayatı içinde herhangi bir toplumsal grup herkese açık kamusal mekânları ve bu mekânların sunduğu kaynak ve hizmetlere erişemiyorsa ya da bunları özgür ve güvenli bir şekilde kullanamıyorsa, kent hakkı kentsel vatandaşlık temelinde ihlal edilmiş olur. Ancak Lefevbre, kentsel vatandaşlık kavramıyla bireyin gündelik hayatını yerel yönetim faaliyetleriyle ilişkilendirirken, cinsiyetlendirilmiş güç ilişkilerinin kentsel yaşam ve mekânsal deneyimler üzerindeki etkilerine kördür (Fenster, 2005). Oysaki kadınların kentle ilişkileri ve gündelik deneyimleri, ataerkil kültür ve eşitsiz toplumsal cinsiyet ilişkilerinin sonucunda kısıtlamalar ve engellemeler etrafında şekillenir. Bu durumun ürettiği kent hakkının ihlaline yol açan cinsiyetçi pratikler ve toplumsal cinsiyete dayalı dişlamalar, kadınların kentsel mekân ve kurumlarla ilişkilerini erkeklerden farklılaştırdığı gibi, aynı zamanda eşitsiz ve dezavantajlı da kılar (Fenster 2005; 1999).

Feminist coğrafya ve kent planlama çalışmalarının ortaya koyduğu üzere, güvenlik ve eşitlik kadınların kent hakkının en temel bileşenini oluşturur. Buna göre, "kent hakkı daha adil, demokratik ve kapsayıcı kentlerde şiddet ve korkudan uzak yaşama hakkını içerir" ve dolayısıyla tüm kadınların yerel yönetim ve kentsel planlama süreçlerine katılımlarının gerekliliğini kabul eder (Falu, 2010; Geniş ve Akkirman, 2020; Kümbetoğlu, 2001; Shaw vd., 2012). Kadınların güvenli, özgür bir biçimde kentsel mekâna erişim ve katılımını sınırlandıran çok sayıda toplumsal faktör bulunmaktadır. Bunların başında, bir yandan ataerkil kültüre bağlı aile içi toplumsal cinsiyet ilişkileri bulunurken, öte yandan kentsel planlama ve hizmetlerin cinsiyetçi ve/ya cinsiyet körü yaklaşımlar tarafından düzenlenip yönetilmesi gelir. Bu nedenle kadınların erişim, katılım ve güvenlik bağlamında kent hakkı, özel alanla kamusal alanı birbirine bağlayan bir süreklilik içinde gelişir. Bu alandaki feminist araştırmaların 80'li yıllardan beri vurguladığı üzere, kadınların kent hayatında eşitsiz ve erkeklere göre dezavantajlı konumunun temel sebebi kentsel mekânın ve yaşamın özel-kamusal ayrımına dayalı toplumsal cinsiyet ide- 
olojisine göre düzenlenmesidir (Alkan, 2005; Geniş ve Akkirman, 2020; Mackenzie, 1989; McDowell, 1983). Kentsel mekânın düzenlenmesi, cinsiyete dayalı işbölümü ve evin işyerinden ayrılmasının sonuçlarını bir yandan yansıtırken bir yandan da bunların üretiminde etkin rol oynar.

Hem ideolojik hem fiziksel olarak kurulan bu ayrım, mekânların kullanım ve işlevlerini düzenlerken ayn zamanda bunlara uygun toplumsal cinsiyet rolleri, davranışları ve ilişkilerini de belirler. Burada gözden kaçırılmaması gereken nokta, kadınların eve ve özel alana erkeklerinse işyerlerine ve kamusal alana ait görülmesine dayanan bu ayrımın her bir alana atfettiği ayrı anlamlar ve değerler seti, sadece cinsiyetler arasındaki eşitsizliği değil mekânsal eşitsizliği de yaratır. Buna göre, kadınlar ev işleri ve çocuk bakımından sorumlu tutuldukları özel alanla sınırlanırken, erkekler ev ile dışarısı, özel ile kamusal alanlar arasında meşru bir şekilde hareket ederler (Valentine, 1989). Kadının ait olduğu varsayılan evden sokağa çıkışı ve kamusal hayata katılması ise endişe yaratan bir durum olarak görülür. Dolayısıyla kadın baskı ve engellerle karşılaşır. Duncan'ın $(1996 ; 128)$ ifade ettiği üzere, özel-kamusal ayrımının politik ve mekânsal yönleri sıklıkla kadınları kontrol ve disipline ederek kamusal mekânların dışında tutmak için kullanılır. Toplumsal cinsiyet temelli baskı ve şiddetin özelden kamusal alana bir süreklilik gösterdiği iddiası tam da bu anlamda karşılık bulur çünkü kadınların gerek olmadıkça özellikle de yalnız dışarı çıkmalarını engellemek ya da onları evde kalmaya teşvik etmek gibi kamusal mekândan dışlayan gündelik kısıtlamalar ev içi şiddetin temelinde yatan sistematik baskıyı da sürdürmeye yarar. Böylelikle kadınların kamusal mekânla gerilimli ilişkisi ve cinsiyetlendirilmiş deneyimi daha evden çımadan özel alanda başlar (Tuncer, 2018). Bu durum, özel ve kamusal hayatın ayrılmaz tek bir sürecin parçaları olarak karşılıklı ilişki içinde oluştuğuna ve dolayısıyla kent hayatının cinsiyetçi yapısının bu iki alanı birbirine bağlayan örüntüler etrafında şekillendiğine işaret eder.

Ev içinde geleneksel cinsiyet normlarına bağlı olarak kadınların kent hayatına ve olanaklarına erişimlerinin kısıtlanması, dışarı çıktıklarında ise kendilerine dayatılan cinsiyetçi kültürel kodlar ya da kamusal mekânlarda yaşadıkları cinsel taciz ve şiddet olaylarıyla devam eder. Feminist coğrafya ve kent çalışmalarında yapılan araştırmalar özellikle kadınların sokağa çıkışlarında ve kamusal mekân deneyimlerinde şiddet, cinsel taciz ve tecavüz korkusunun belirleyici olduğunu ve bu yüzden kent hayatına katılımlarının k1sitlandığını vurgulamıştır (Koskela, 1997; Lordoğlu, 2016; 2018; Pain, 1991; 2000; Valentine, 1989). Kadınlar sokakta, toplu taşımada veya parklarda cinsel taciz ve saldırıya uğradıkları gibi, hem taciz korkusu ve güvenlik riski 
hem de kadın bedeni ve cinselliğine yönelik sosyo-kültürel ahlak kodları nedeniyle kentin belli bölgelerinde ve kamusal mekânlarında tek başlarına ya da geç saatlerde bulunamazlar (Fenster, 1999; Massey,1994; Tuncer, 2018). Dolayısıyla kadınlar için kamusal mekânda şiddet korkusu ve deneyimi son derece cinsiyetlendirilmiş olup, bu korku bir temele dayansın ya da dayanmasın bireyselden ziyade toplumsal (ve aynı zamanda mekânsal) olarak inşa edilir. Bu anlamda, "cinsel taciz kadınların kamusal yaşamdan daha geniş anlamda dışlanmasını pekiştirme ve yeniden üretme işlevi gören ataerkilliğin mekânsal bir ifadesi olarak anlaşılabilir (Vera-Gray ve Kelly, 2020)."

Cinsel tacize uğramanın yanı sıra, bunun ihtimaline karşı duyulan korku ve tehlike, kadınların gündelik hayatlarında kent kamusal mekânlarına erişimlerini ve bu mekânları kullanımlarını sınırlayarak belirler. Bu durum, kadınların hareket özgürlügünü kısıtlayarak kent hakkının sağladığı firsat ve olanaklardan erkeklerle aynı şekilde ve eşit olarak faydalanmalarını engeller (Fenster, 2005). Kadınlar işe gitmek, alışveriş yapmak, çocukları okula ve hastaneye götürmek ya da diğer ailevi sorumluluklarını yerine getirmenin yanı sıra kendi ihtiyaçlarını gidermek, cinsel sağlık ve üreme sağlığı hizmetlerinden yararlanmak için kent kamusal mekânlarını yaşadıkları mahallelerden başlayarak farklı ölçeklerde kullanırlar. Bu bağlamda kamusal mekâna erişim ve onu kullanım hakkı, insanın hayatını sürdürmesinin ana gereksinimleri olan beslenme, barınma ve sağlık gibi temel insan haklarıyla iç içe geçer (Kaplan, 1997). Bu durum yoksul, göçmen ve mülteci gibi dezavantajlı kırılgan gruplardaki kadınlar açısından çok daha ağır sonuçlar yaratırken, salgın veya afet gibi acil durumlarda, özellikle de kriz/çatışma bölgelerinde bulunan ya da zayıf sağlık sistemi ve sosyal hizmetlere sahip kentlerdeki kadın ve kız çocukları için yaşamsal bir mesele haline gelmektedir. Örneğin Covid-19 pandemisi sürecinde birçok kadın işçi, toplu taşıma araçlarından uzak durmak için işe yürüyerek veya bisikletle gitmenin bedeli olarak cinsel tacizin arttı̆̆ını bildirmiştir (BM Kadın, 2020b). Buna ek olarak, çeşitli ülkelerde salgınla birlikte kamusal düzeni sağlamaya yönelik alınan önlemlerin uygulanması kamusal mekânların militarizasyonunun artmasıyla sonuçlanmış olup, bu da kolluk kuvvetleri ya da güvenlik görevlileri tarafından gerçekleştirilen kadınlara ve kız çocuklara yönelik cinsel taciz ve şiddet riskini arttırmıştır (BM Kadın, 2020b). Tüm bu durumların sonucunda kamusal mekânların güvensiz ve tehlikeli hale gelmesi, kadınların hayatların idame ettirmek için ihtiyaç duydukları kaynak ve hizmetlere erişimlerini tümüyle engellemese bile, bunun için ekstra çaba göstermelerini veya bedelini cinsel taciz ve şiddetle ödemelerini zorunlu kılar. 
Şüphesiz kadınların kent deneyimleri sadece korku üzerine kurulmadığı gibi kent hakkı da güvenlik ve şiddetten korunma ile sınırlı değildir. Kadınları kentle ilişkilerinde sadece mağdur ya da şiddet kurbanı olarak değil, aynı zamanda kentsel mekânın aktif üreticileri olarak kamusal mekânları kendilerine özgü şekillerde ve çeşitli stratejilerle sahiplenerek talep eden toplumsal özneler olarak görmek gerekir. Listerborn'un (2016) ifade ettiği üzere, kent hayatında kadınların aktif katılımcılar ve mağdurlar olarak dengeli bir temsili oldukça karmaşık bir meseledir. Ancak burada toplumsal cinsiyet temelli şiddetin kadınların gündelik kent deneyiminin içkin bir parçası olduğunun altı çizilmelidir. Kadınlar tehlikeden uzak durmak veya tehlikeyle karşılaştığında riski en aza indirmek için kent kamusal mekânlarında sürekli tetikte davranmak zorunda kalarak davranış ve hareketlerini değiştirmek ya da ayarlamak durumunda kalırlar. Cinsel şiddete maruz kalma riskine karşı genelde bedensel ve mekânsal kısıtlamalar şeklinde yapılan bu uyarlamalar, kadınların özgürlüğünün sınılarını çizerken, aynı zamanda omuzlarına gündelik hayatın içinde adeta rutin hale dönüşen görünmez bir "güvenli olma mesaisi" (safety work) yükler (Kelly, 2012). Bu durum kadınları marjinal bir konuma iterek kent hayatından dışlanmasına ve kamusal mekanlara ait hissetmemesine neden olur -ki bu da kent hakkı ihlalinin kadınlar için gündelik bir pratik olması anlamına gelir (Fenster, 2005). Dolayısıyla kadınlar gündelik hayatlarında ancak bu "cinsiyetlendirilmiş faaliyet"ten kurtularak kamusal mekânları kendi şartlarına göre özgürce kullanıp aidiyet geliştirdikleri zaman kent hakkını tam anlamıyla gerçekleştirmiş olurlar (Vera-Gray ve Kelly, 2020).

\section{Araştırmanın Yöntemi}

Covid-19 pandemisi sürecinde uygulanan önleyici tedbirlere ve kısıtlamalara bağlı olarak yeniden düzenlenen kamusal mekânın gündelik hayatta toplumsal cinsiyet rolleri ve pratikleri açısından farklılaşan deneyimleme biçimlerini incelemek için araştırma kapsamında gazete haberleri ve sosyal medya paylaşımlarından yararlandık. Kamusal mekânla ilgili çalışmalarda genelde yoğun gözlem ve görüşme tekniklerinin kullanıldığı etnografya yöntemlerine başvurulsa da, salgın koşullarının araştırmacılar için de önemli bir kısıtlama ve engelleme teşkil etmesi nedeniyle internet üzerinden ulaşabileceğimiz çevrimiçi yöntemlerle veri toplamaya karar verdik. Bu süreçte birçok araştırmacı söz konusu kısıtlamaları aşabilmek için teknolojinin ve sosyal medyanın imkânlarından faydalanarak, anket veya görüşmelerini çevrimiçi platformlara taşıdı ya da Zoom gibi sesli ve görüntülü görüşme uygulamalarıyla yü- 
rüttü. Ayrıca, kentsel sosyo-mekansal etkileşimlerin daha kapsamlı bir görüntüsünü çıkarmak için konumsal medya araçlarını kullanarak coğrafi etiketli veri toplama da bu süreçte oldukça yaygın kullanılan yöntemlerden biri olmuştur (örnek için bkz. Iranmenesh ve Alpar Atun, 2020). Biz ise bu çalışmada koronavirüsün görülmesiyle ortaya çıkan 'yeni normal'de kent kamusal mekânlarına getirilen kısıtlamaların, insanların gündelik hayatında nasıl karşılık bulduğunu ve bunlarla nasıl baş ettiklerini ya da edemediklerini gazete haberlerine ve twitter özelinde sosyal medya paylaşımlarına yansımaları üzerinden incelemeyi tercih ettik.

İki farklı mecrayı kullanarak veri toplamasını gerçekleştirdiğimiz araştırmada ilk olarak; salgında hükümet ve yerel yönetimler tarafından kamusal mekânların kullanımına yönelik kısıtlayıcı tedbirler karşısında kadınlar ve erkeklerin nasıl tepki verdikleri ve ne tür davranışlar sergilediklerini incelemek için en çok satan beş gazetenin dijital arşivinde belirli anahtar kavramlar eşliğinde tarama yaptık. Gazete taramasını yapmak için ilk koronavirüs vakasının görüldüğü 10 Mart 2020 tarihinden başlayarak yasakların kaldırıldığı ve "yeni normalleşme" sürecinin başladığı 1 Haziran 2020 tarihine kadar geçen süreyi belirledik. Bu tarih aralığındaki tiraj sıralamasına göre araştırma için seçtiğimiz en çok satanlar arasında yer alan beş gazete; Sabah, Hürriyet, Sözcü, Milliyet ve Posta gazeteleridir. ${ }^{6}$ Yapılan ön araştırma sonucunda, gazete haberlerine yansiyan yasak ve kısıtlamalarla ilgili yapılan ihlaller ya da yeni sosyalleşme biçimleri ve mekân kullanımlarını ortaya çıkarmaya yönelik toplumsal cinsiyete bağlı farklılaşan sosyo-mekânsal pratikleri gözeterek çeşitli anahtar kelimeler seçtik. Ön araştırma sırasında gazete taraması için çok sayıda farklı kelimeyle arama yapılmasına karşın, gündelik kamusal mekân deneyimlerinin genelde sıradan pratik ve eylemler içermesi nedeniyle konumuzla ilgili spesifik haberleri ayırt etmek açısından bu aramalar işlevsel olmamıştır. Bunun sonucunda araştırmamızl, salgınla birlikte gündelik kent hayatı içinde kamusal mekân deneyimini dönüştüren yasak ve kısıtlamalardan öne çıkanlara ilişkin belli başlı kelimelerle sınırlandırmaya karar verdik. Bu sinırlandırmayı yaparken gazete ve televizyon haberlerine yoğun olarak

\footnotetext{
${ }^{6}$ Gazete tirajlarına ulaşmak için "gazetetirajları.com” adresinden yararlanılmıştır. Bu site içerisinde tarihe göre arama yapmak ve haftalık olarak gazete satışı sayılarına ulaşmak mümkündür: http://gazetetirajlari.com/. Araştırmayı yürüttüğümüz tarih aralığında (10 Mart - 1 Haziran 2020) tiraj sıralamasında en çok satan ilk beş gazete kendi içinde yer değiştirmekte olup kimi haftalarda ise bu listeye Türkiye Gazetesi girmektedir. Biz çalışma kapsamında haberlerin farklı politik eğilimlere sahip gazetelerde nasıl temsil edildiğiyle ilgilenmediğimiz için daha fazla haber ve görsele ulaşma imkânı sağlayan Milliyet Gazetesi'ni tercih ettik.
} 
yansıyan ve sosyal medyada dolaşıma giren ihlal olaylarını ve yeni sosyalleşme pratiklerini takip ettik.

Tablo 1. Haber taraması için seçilen gazeteler ve anahtar kelimeler

\begin{tabular}{lll}
\hline Gazeteler & Anahtar Kelimeler & \\
\hline Sabah & Banklar & Bahçede \\
\hline Hürriyet & Balık tutulması & Balkonda \\
\hline Sözcü & Balık avlamak & Pencerede \\
\hline Milliyet & Kahvehane & Apartmanda \\
\hline Posta & Kıraathane & Apartman İçinde \\
\hline
\end{tabular}

Gazete taraması sonucunda ulaştığımız haberlerin büyük çoğunluğu erkeklerin kamusal mekâna ilişkin kısıtlama ve yasakları ihlal ettikleri olayları konu ederken, kadınlara ilişkin haberler evin uzantısı ve çevresindeki yarı kamusal/yarı özel alanlarda salgınla birlikte ortaya çıan yeni sosyalleşme pratikleri ve mekân kullanımlarıyla sınırlıydı. Bu haberlerin de çok az sayıda olması sebebiyle, kadınların salgın sürecinde değişen gündelik sosyomekânsal pratikleriyle ilgili daha fazla bilgiye ulaşmak amaciyla popüler sosyal medya uygulaması Twitter sitesinde yapılan paylaşımları incelemeye karar verdik. Bu kararımızda, diğer sosyal medya uygulamalarına göre Twitter'ın daha hızlı ve spontane bir "ileti akışı" sağlaması ve böylelikle kadınların gündelik hayat deneyimlerini gözlemleme imkanı vermesi belirleyici oldu (Karataş ve Binark, 2016). Buradan hareketle, gazete taraması sonuçlarına da paralel olarak, kadınların gündelik hayatlarında önemli rol oynayan ancak salgınla birlikte vazgeçilmez hale gelen balkon, pencere ve bahçe gibi ev çevresindeki yarı kamusal-yarı özel alanları kullanma pratiklerine ilişkin Twitter paylaşımlarını, gündelik terminolojiye uygun olacak şekilde belirlediğimiz anahtar kelimeler aracılığıyla inceledik. Gelişmiş ayarları sayesinde tarih aralığı saptanarak kelime/ler aracılığıyla arama yapmanın mümkün olduğu Twitter'da, araştırmamız kapsamında 1 Ocak ile 31 Temmuz 2020 tarihleri arasındaki yedi ay süresince belirli sosyalleşme ve mekânsal ifadelerin taramasını çeşitli kombinasyonlar eşliğinde gerçekleştirdik.7

\footnotetext{
${ }^{7}$ Araştırmanın başlangıç tarihi olarak 1 Ocak 2020 tarihini seçmemizin nedeni, Türkiye'de salgın sürecinin başlangıç tarihinin öncesinden başlayarak kadınların gündelik mekân deneyimlerini bütünlüklü bir şekilde anlamaya çalışmaktır. Yine aynı nedenle, bitiş tarihini de 1 Haziran 2020 'den itibaren başlayarak yasakların kalktığı ya da esnediği zamanı kapsayan ve "yeni normalleşme" olarak adlandırılan dönemin devam ettiği 2020 Temmuz ayı da çalışmaya dâhil edilmiştir.
} 
Tablo 2. Twitter incelemesi için kullanılan anahtar kelimeler

\begin{tabular}{ll}
\hline Sosyalleşme İfadeleri & Mekânsal ifadeler \\
\hline Gün yaptık & Pencerede \\
\hline Gün yapmak & Balkonda \\
\hline Sohbet ettik & Apartmanda \\
\hline Görüştük & Bahçede \\
\hline Oturduk & \\
\hline Buluştuk & \\
\hline
\end{tabular}

Ayrıca, araştırma kapsamında kadınların salgın sürecinde özel alandan kamusal mekânlara uzanan farklı ölçeklerde yaşamış oldukları cinsel taciz ve erkek şiddetine ilişkin gündelik deneyimlerinin Twiter'daki paylaşımlara ne kadar yansıdığını anlamak için yine aynı tarih aralığında (1 Ocak - 31 Temmuz 2020) konuyla ilgili anahtar kelimeler belirleyerek ayrı bir tarama daha yaptık. Kadınların hem evde ve ev çevresinde hem de kamusal mekânlarda erkekler tarafından uğradıkları farklı şiddet biçimlerini kapsayacak şekilde belirlediğimiz anahtar kelime ve ifadeler şöyledir: taciz edildim, tacize uğradım, taciz etti, takip edildim, takip etti, dayak yedim, dövüldüm, dövdü, darp edildim, darp etti, şiddet gördüm, şiddete uğradım ve şiddete maruz kaldım. Bunlara ek olarak, pandeminin başlangıcında yaygın olarak kullanılmaya başlanan karantina sözcügünü ev, sokak, dayak, dövdü, darp ve şiddet kelimeleriyle kombinasyon yaparak koronavirüs vakasının ilk kez görüldüğü 2020 Mart ayı özelinde taradık. Ayrıca, pandemiyle birlikte uygulanan mekan ve hareket kısıtlamaları nedeniyle zorunlu olarak artan online alışveriş ve siparişin artmasına bağlı olarak, Twitter'da "kargo, kargocu, kurye ve kuryeci" kelimelerini taciz ve mesaj kelimeleriyle sırayla eşleştirerek yaptığımız aramayla bu süreçte dijital taciz ve evin kamusala açılan kapı eşiğinde yaşanabilecek taciz ve şiddete ilişkin paylaşımları ortaya çıkarmaya çalıştık. Son olarak, geçtiğimiz yıllarda Twitter'ın erkek şiddetine uğrayan kadınlar tarafından giderek bir yardım ve destek isteme platformu olarak kullanılmasından yola çıkarak, "şiddet" kelimesini "yardım edin" ve "sesimi duyun" ifadeleriyle ayrı ayrı eşleştirerek bir tarama gerçekleştirdik. Tüm bu aramaların sonucunda, pandemi sürecinde kadınların hem ev içinde hem de kapı eşiği, balkon ve pencere gibi özelden kamusala açlan evin uzantılarında ve ayrıca kentin açık kamusal mekânlarında yaşadıkları farklı şiddet biçimlerine ilişkin sosyal medyada yaptıkları kişisel paylaşımlar üzerinden veri elde etmiş olduk.

Araştırma kapsamında hem inceleme alanı olarak sosyal medya uygulamalarından Twitter' 1 seçmeden önce hem de tarama yaparken kullandığımız 
anahtar kelimeleri belirlemek için yaklaşık iki hafta ön araştırma yaptık. Bunun sonucunda, ara yüzlerinin akıllı telefonlarda rahatça kullanılabildiği için anlık olarak paylaşım yapılmasına imkân vermesi ve böylelikle gündelik hayatın akışına kolayca dâhil olabilmesinin yanı sıra, sitede yapılan paylaşımları sistemli ve pratik bir şekilde aramanın mümkün olması nedeniyle Twitter'ın incelememiz için uygun olduğuna karar verdik. Ön araştırma sırasında elde ettiğimiz bir diğer sonuç ise, kadınların Twitter'da kişisel deneyimlerini aktarırken çoğunlukla etiket kullanmadıkları ve gündelik hayata ilişkin bireysel paylaşımların bir gündem haline gelmediği için Trend Topic listelerinde genelde yer almadığı oldu. Bunun üzerine, yeterince etkileşim almadığı için popüler tweetler arasında yer almayan paylaşımların inceleme kapsamının dışında kalmasını engellemek için, Twitter araştırmasını etiket (hashtag) ya da Trend Topic ${ }^{8}$ listeleri yerine anahtar kelimeler üzerinden yürüterek açık hesaplar tarafından yapılan paylaşımları incelemeyi tercih ettik. Bununla beraber, araştırma kapsamında Twitter'da paylaşımlarını incelediğimiz hesaplarla doğrudan ya da dolaylı olarak bir etkileşime girmeyip, sadece yapılan paylaşımların içerdiği kişisel deneyim aktarımlarına odaklandık. Söz konusu tweetlere gelen etkileşim ve cevapları gözlemlemekle birlikte incelemeye dâhil etmedik. Araştırma konumuzla ilgili incelemeye aldığımız Twitter paylaşımlarını ise "ekran görüntüsü" (screen shot) ${ }^{9}$ alma tekniğinden yararlanarak kayıt altına aldık ve elde ettiğimiz verileri kullanırken etik ilkeler gereğince paylaşımları yapan hesapların isimlerine yer vermeyip kullanıcıları anonimleştirdik. ${ }^{10}$

\footnotetext{
${ }^{8}$ Trend Topic listelerine ulaşmak için "trendogate.com" adresinden yararlanılmıştır. Bu site içerisinde tarih bazlı arama yapılmaktadır. Bunun yanı sıra Twitter' da hem Türkiye gündeminde yer alan hem de diğer ülkelerin gündemine bağlı olarak oluşan Trend Topic listelerine ulaşmak mümkündür. Ayrıca site içerisinde etiket (hashtag) üzerinden de arama yapılabilmektedir. Ayrıntılı bilgi için bakınız: https://trendogate.com/place/23424969.

${ }^{9} \mathrm{Bu}$ yöntemin uygulanması için çeşitli yazılımlar kullanılabileceği gibi, bilgisayarlardaki 'print screen' seçeneğinden de yararlanarak da yapılabilir. Böylece ekran üzerinde var olan görüntü kopyalanabilmekte ve dosyanın kaydedilmesi yoluyla arşivlenmesi sağlanmaktadır. Ayrıntılı bilgi için bakınız: Çomu T. ve İ. Halaiqua. (2015). "Web İçeriklerinin Metin Temelli Çözümlenmesi". Editör Mutlu Binark, Yeni Medya Çalışmalarında Araştırma Yöntem ve Teknikleri. İstanbul: Ayrıntı Yayınları, s. 35.

${ }^{10}$ Sosyal medya üzerine araştırma yapan araştırmacıların, dünyada ve Türkiye'de kişisel verilerin korunması ile ilgili olan yasal mevzuatın gelişmesi nedeniyle sosyal medya ortamından elde ettikleri verileri etik ilkeler temelinde değerlendirme sorumluluğu vardır. Ayrıca kullanıcı “özne”nin bu veriler ile olan bağı göz önünde bulundurularak kullanılması gerekmektedir. Bu nedenle sosyal medya platformlarından elde edilen kamuya açık verilerin de anonimleștirilmesi sağlanmalıdır. Ayrıntılı bilgi için bakınız: Mutlu, B. ve Şafak Dikmen E. (2020). Neden İnternet ve Yeni Medya Araştırmalarında Araştırma Etiği Gerekli?. Ankara: NETlab Yeni Medya Araştırmaları Laboratuvarı, s.6- 68.
} 
Son olarak, bu çalışmayı yürütürken sosyal medya uygulaması Twitter kullanıcilarının toplumun genelini temsil eden homojen bir örneklem oluşturduğunu varsaymadık. Hem akıllı telefon ve bilgisayar gibi teknolojik aletlere sahip olmanın hem de internete erişimin sınıf, cinsiyet ve yaş gibi çeşitli dinamiklerle belirlenmesi nedeniyle sosyal medya kullanıcılarının da genel olarak buna göre kısıtlı bir profil sergileme tehlikesi vardır. Araştırma kapsamında incelediğimiz twitter paylaşımlarının ağırlıklı olarak genç kadınlar tarafından yapıldığı gözlenmekle birlikte, Twitter uygulaması aracılığıyla kullanıcıların profiline dair bilgi edinmek mümkün olmadığı için belirli bir kadın grubu ya da kadın grupları yerine tweetlerin içerdiği kadınlık deneyimleri esas alınmıştır. Ayrıca, Twitter üzerinde belli bir tarih aralığında anahtar kelimeler aracılığıyla yapılan taramada toplam verinin ancak sınırlı bir miktarına ulaşılmaktadır (Kim vd., 2013). Bu kısıtlılıklara rağmen yine de Twitter verileri, diğer veri toplama yöntemlerinin elverişsiz ya da güvensiz hale geldiğinde, kentin gündelik hayatına dair benzeri görülmemiş öngörüler sağlayabilir (Iranmenesh ve Alpar Atun, 2020).

\section{Salgın Tedbirlerine Karşı Kamusal Mekânda Cinsiyetlendirilmiş Pratikler}

Türkiye'de Covid-19 pandemisinin toplumsal cinsiyete bağlı etkileri üzerine değerlendirmelerin genel olarak kadın emeği ve toplumsal cinsiyet temelli şiddet alanlarında yoğunlaştığı gözlenmektedir. Kadın emeği konusunda yayınlanan çalışma ve raporlar, salgınla birlikte kamusal alandaki temel faaliyetlerin özel alana taşınması sonucunda bir yandan kadınların ev içinde iş yükünün ve bakım emeğinin ezici bir biçimde artışına, bir yandan da kadınların istihdam alanında yaşadıkları işten çıkarılma, ücret düşüklüğü ve ağır mesai gibi sorunlara dikkat çekmişlerdir (Bayar, Günçavdı ve Levent 2020; İlkkaracan ve Memiş, 2020). Toplumsal cinsiyet temelli şiddet konusunda ise odak noktası, eve kapanmayla birlikte kadınların hane içinde eşleri veya yakınlarındaki erkekler tarafından uğradıkları şiddetin dramatik biçimde artışı olmuştur (Ergören, Biçen ve Ersoy, 2020; SAHA, 2020). Salgın sürecinde uygulanan tedbirlerin ve kanuni düzenlemelerin doğrudan ya da dolaylı etkisiyle erkek şiddeti ve kadın cinayetlerindeki yükseliş, ulusal ve uluslararası sivil toplum kuruluşları ve kadın örgütleri tarafından hazırlanan çeşitli raporlar ve verilerle ortaya koyulurken (KCDP, 2020; SAHA, 2020) kadınların salgın sürecinde kamusal alanda ve mekânlarda yaşadıkları cinsel taciz ve şiddet olgusuna yer verilmemiştir. Öte yandan, salgından korunmak için uygulanan önleyici tedbirler ve kısttlamaların kamusal mekânlar ve kent haya- 
tını nasıl etkilediğine ilişkin ağırlıklı olarak mimarlar ve planlamacılar tarafindan yayınlanan değerlendirmelerde ise, toplumsal cinsiyet boyutu genelde ihmal edilmiş olup kamusal mekânın yasak ve kısıtlamalara bağlı olarak yeniden düzenlenmesinin cinsiyetlendirilmiş roller ve pratikler açısından ne gibi sonuçlar doğurduğu sorusuyla ilgilenilmemiştir. Çalışmanın bu bölümünde, hem toplumsal cinsiyet araştırmaları hem de kent ve mekân çalışmalarında Covid-19 pandemisinin etkileri incelenirken gözden kaçırılan bu soruyu, salgında toplumsal cinsiyete bağlı olarak farklılaşan sosyo-mekânsal deneyimlere ilişkin gazeteye yansiyan haberlerden ve popüler sosyal medya uygulaması Twitter paylaşımlarından elde ettiğimiz veriler aracilığıyla ele alacağız.

Dünya Sağlık Örgütü'nün 11 Mart 2020 tarihinde Covid-19'u bir pandemi ilan etmesinin ardından, diğer tüm ülkelerde olduğu gibi Türkiye'de de hem hükümet tarafından hem yerel yönetimler tarafından çok sayıda kısıtlayıcı önlem alınmıştır. Alınan ilk önlemlerden biri ilkokul, ortaokul ve lise eğitimine bir hafta ara verilmesi ve üniversitelerin üç haftalık tatil edilmesi kararı olmuştur. Ancak vakaların kısa sürede artmasıyla birlikte, okulların kapatılarak uzaktan eğitime geçilmesi ve kamu işlerinde esnek çalışma vb. uygulamaları kapsayan çok daha geniş tedbirler uygulanmıştır. Bu süreçte, özellikle gündelik kamusal mekânların kullanımının kısıtlanmasına yönelik çok sayıda karar çıkarılmıştır. Bunlardan belli başlı olanları şöyle sıralayabiliriz: cami ve mescitlerin kapatılması, kafe, nargile salonu, kahvehane gibi mekânların kapatılması, lokanta ve restoranlarda bulunan masa ve sandalyelerin kaldırılması ve yalnızca paket servise izin verilmesi, berber ve kuaförlerin kapatılması (TRT Haber, 21 Nisan 2020). Bu önlemlere, 21 Mart 2020 tarihinde İçişleri Bakanlığı tarafından yayınlanan genelge ile birlikte 65 yaş ve üstünde olan kişilerin sokağa çıkmasının yasaklanması da eklenmiştir (T.C. İçişleri Bakanlığı, 2020). Yaş temelli getirilen bu yasak, 3 Nisan 2020 tarihinde cumhurbaşkanı tarafından yapılan basın açıklamasında 20 yaş altında olan gençleri ve çocukları da kapsayacak şekilde genişletilmiştir. Gün geçtikçe artan vaka sayıları ile birlikte bu sınırlamalara 11 Nisan 2020 tarihi itibariyle hafta sonları sokağa çıkma yasağı da eklenmiş olup, bu süreçte sokağa çıkan kişiler hakkında ise yasal işlem başlatılmıştır. Tüm bu kısıtlamalar, hem özel alanda hem de kamusal mekânlarda sosyal yaşamı ciddi düzeyde etkileyen ve gündelik hayat içerisinde mekânsal hareketliliğin sınırlandırıldığı yeni ve olağandışı bir deneyim hali yaratmıştır. 
Kent hayatını ve sosyo-mekânsal pratikleri son derece kısıtlayan ve hatta yer yer engelleyen bu tedbir kararlarının gündelik hayata en belirgin yansımalarından biri, alışılagelen 'normal' in terk edilerek özel ile kamusal arasındaki sınırların değişimini zorunlu kılması olmuştur. Bu aynı zamanda, gündelik hayatın ve mekânların geleneksel toplumsal cinsiyet normlarına göre düzenlenip deneyimlenmesinin de temelinden sarsılması anlamina gelir. Çünkü Türkiye toplumsal hayatının örgütlenişinde özel ile kamusal alan arasındaki ayrışma, gerek fiziksel gerek ideolojik olarak son derece cinsiyetlendirilmiş olarak belirlenmiştir. Bu nedenle, insanların salgınla birlikte mecburi olarak bir anda hayatlarına giren bu uygulamalara ilk başlarda verdikleri tepkiler, sadece rutin hale gelen gündelik mekânsal pratiklerinin bozulmasıyla değil, aynı zamanda yerleşmiş geleneksel toplumsal cinsiyet rollerine göre hareket etmeyi sürdürememeleriyle de yakından ilgilidir. Bu durumun sonuçları, konuyla ilgili yaptığımız 10 Mart-1 Haziran 2020 tarih aralığına ilişkin gazete dijital arşiv taramasında da ortaya çıardığımız üzere, gazete haberlerine yoğun bir biçimde yansımıştır. İlk vakanın görülmesinin ardından geçen yaklaşık üç aylık sürede en çok satan beş gazetede salgınla birlikte yapılan kamusal mekân düzenlemeleriyle ilgili ulaştı̆̆ımız toplam 340 haberin yarıdan fazlasının toplumda yaygın olarak erkek mekânı kabul edilen kahvehane ve kıraathaneler olması oldukça dikkat çekicidir.

Tablo 3. Gazete taraması sonucunda ulaşılan haber sayısının dağılımı

\begin{tabular}{|c|c|c|c|c|c|c|}
\hline & 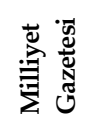 & 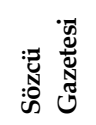 & 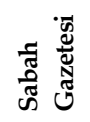 & 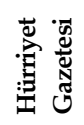 & 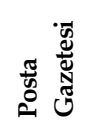 & $\sum_{\substack{\sin \\
0}}$ \\
\hline $\begin{array}{l}\text { Balık Avlama } \\
\text { Yasağı }\end{array}$ & 7 & 3 & 4 & 8 & 2 & 24 \\
\hline $\begin{array}{l}\text { Bankların } \\
\text { Kaldırılması }\end{array}$ & 20 & 14 & 8 & 24 & 3 & 69 \\
\hline $\begin{array}{l}\text { Berber ve } \\
\text { Kuaförler }\end{array}$ & 15 & 4 & 14 & 8 & 2 & 43 \\
\hline $\begin{array}{l}\text { Kahvehane ve } \\
\text { Kuraathane }\end{array}$ & 58 & 24 & 33 & 76 & 1 & 192 \\
\hline $\begin{array}{l}\text { Kadınların } \\
\text { Yeni } \\
\text { Sosyalleşme } \\
\text { Biçimleri }\end{array}$ & 2 & 3 & 3 & 4 & - & 12 \\
\hline Toplam & 102 & 48 & 62 & 120 & 8 & 340 \\
\hline
\end{tabular}

Gazete taramasının bir diğer önemli sonucu ise, kamusal mekân kısıtlamalarıyla ilgili haberlerin büyük çoğunluğunun erkeklerin ihlallerini konu etmesidir. Buna karşın, konuyla ilgili kadınların deneyimleri hakkında sınırlı 
sayıda (12) haber yayınlanmış olup, bunlar da genelde kadınların salgınla birlikte geliştirdikleri yeni sosyalleşme pratiklerini içermektedir. Bu başlık altında toplanan haberlerin tümü evin uzantısı ve çevresindeki yarı kamusal/yarı özel mekânlarda gerçekleşen gündelik faaliyetlerle ilgilidir. Bu arada "gün yaptık" ifadesi hariç herhangi bir cinsiyete özgü faaliyet ya da mekân içermeyen kelimelerle yapılan tarama sonucunda çıkan haberlerin hepsinin kadınlarla ilgili olduğunu belirtmemiz gerekir (Bu durum twitter aramaları için de geçerlidir). Bu sonuçlar, Türkiye'de gündelik hayatta mekânsal deneyimin toplumsal cinsiyet rollerine bağlı olarak özel-kamusal ikiliği ekseninde ayrışmasının ne kadar keskin olduğunu ortaya koymaktadır. Buradan hareketle, bu bölümün ilk kısmında gazete taramasıyla elde ettiğimiz veriler 1ş1ğında erkeklerin kamusal mekân kısıtlamalarına yönelik ihlal girişimlerini toplumsal cinsiyet ve mekân ilişkisi perspektifinden inceleyeceğiz. İkinci k1sımda ise kadınların salgında kısıtlamalarla baş etmek için geliştirdikleri yeni sosyalleşme biçimleri ve mekânsal pratiklerini ağırlıklı olarak Twitter paylaşımları aracılığıyla ve aynı zamanda gazete taramasında ulaştığımız kısıtlı sayıdaki haberlerle destekleyerek ele alacağız.

\section{"Sokağın Sahibi" Eve Sığamayan Erkekler}

Covid-19 pandemisinin Türkiye' de görülmeye başlandığı yaklaşık ilk üç aylık döneminde kamusal mekân kısıtlamalarıyla ilgili gazete haberlerine yansiyan olaylar, salgından korunma tedbirleri altında yürürlüğe giren dört mekânsal düzenleme etrafında yoğunlaşmıştır: kahvehane/kıraathanelerin kapatılması (192 haber), bankların kullanımına yönelik girişimler (69 haber), berber/kuaförlerin faaliyetlerinin sonlandırılması (43 haber), balık tutmanın yasaklanması (24 haber). Biz bu çalışma kapsamında kent günlük hayatında kamusal mekân kullanımları ve sosyalleşme pratiklerine odaklandığımız için işyeri faaliyeti kapsamında ayrı bir tartışma alanı olan kuaför ve berberlerin kapatılmasıyla ilgili haberleri incelememizin dışında bıraktık. ${ }^{11}$ Geriye kalan üç düzenlemeden ise toplumsal cinsiyet ve mekân ilişkisini tartışmak açısından ayrıca önem taşıması nedeniyle bankların kullanımı ve kahvehane/kıraathaneler ile ilgili uygulamalara odaklanmayı tercih ettik. Dolayısıyla bu bölümde ilk olarak bankların kullanımı üzerinden açı kent kamusal mekânla-

\footnotetext{
${ }^{11}$ Berber ve kuaför salonlarına yönelik düzenlemeler hem erkek berberlerini hem de kadın kuaförlerini de içeriyordu. Ancak gazete taramasında kapatılma kararına yönelik erkeklerin ihlalleri üzerine çok sayıda haber bulurken, kadınların bu yasağı ihlal ettiğine değinen bir habere ulaşamadik.
} 
rında yapılan kısıtlamalara erkeklerin verdikleri tepkileri, sonrasında ise kapalı mekânlara yönelik yine erkekler tarafından yapılan ihlalleri kahvehane/kıraathane örneğinde tartışmaya açacağız.

Salgının başlamasıyla birlikte hem hükümetin hem de yerel yönetimlerin günlük hayatta mekânsal hareketliliği kısıtlamak ve kamusal faaliyetleri en aza indirmek amacıyla aldığı tedbirlerin başında insanların sokaklardan çekilmesine yönelik önlemler gelmiştir. Gazete haberlerine baktı̆̆ımızda, açık kamusal mekânları kısıtlayan düzenlemeler arasında özellikle bankların kullanımının engellenmesine yönelik girişimlerin ön plana çıktı̆̆ görülmektedir. Salgında kamu sağlığını korumak amacıyla birçok belediye, alınan tedbir kararlarına vatandaşların uymasını sağlamak için meydanlarda, caddelerde, ara sokaklarda ya da sahil bantlarında bulunan ve insanların dinlenmek için oturdukları ya da bir araya gelerek sohbet ettikleri bankların çevresini şeritlerle veya demir bariyerlerle çevirmişlerdir. Ancak tüm bu girişimlere rağmen, erkeklerin özellikle de ileri yaşlarda ve çalışmayanların belediyeler tarafından koyulan şeritleri kaldırarak ya da demir bariyerlerin üzerinden atlayarak banklarda oturmaya çalıştıkları sıklıkla haberlere konu olmuştur. Erkeklerin dışarıda nasıl vakit geçirip sosyalleşeceklerinin adeta bir krize dönüştüğü bu durum, bazı belediyelerin kendi sınırlarında bulunan bankların tamamını kaldırmasıyla sonuçlanmıştır. Sözcü gazetesinin bu olayla ilgili verdiği habere göre; Sivas'ta belediye ekipleri salgin tedbirleri kapsamında sokaktaki bankları sökünce, erkekler "biz şimdi nereye oturacağız?" diye tepki göstermişlerdir (bkz. Şekil 1). Başka haberlerde de yer alan bu ve benzeri ifadeler, sokakları terk etmeye direnç gösteren erkeklerin, evin dışında geçirdikleri zamanı nerede ve nasıl dolduracaklarını da bilemediklerini göstermektedir. Sözcü gazetesinin 21 Mart 2020 tarihli bu haberindeki diğer bir dikkat çekici nokta ise, haber başlığının "Yaşlıları evde tutamıyoruz: 'Biz şimdi nereye oturacağız?" şeklinde verilmiş olmasıdır. Haber içeriğine ve görseline baktığımızda ise, aslında başlıkta bahsedilen evlere girmek istemeyen "yaşlılar" tanımlamasıyla erkeklerin kastedildiği anlaşılmaktadır. Yine bu konuyla ilgili bir başka haberde ise Edirne'de belediyenin caddelerdeki yoğunluğu azaltmak amacıyla bankları sökmesi karşısında, d1şarıda nereye oturulacağı sorununa çözüm olarak bir erkeğin caddeye yanında sandalyeyle geldiğine yer verilmiştir (Sözcü, 19 Mart 2020). 


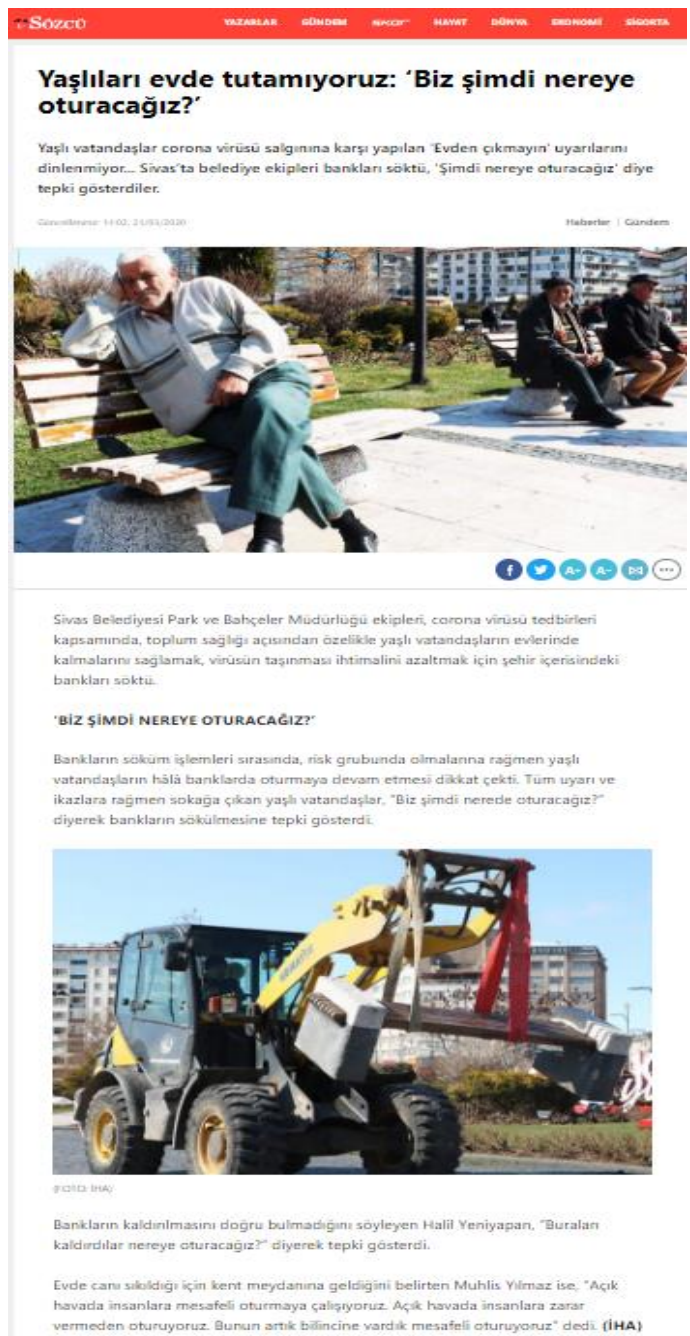

Şekil 1. Bankların kaldırılmasıyla ilgili Sözcü Gazetesi haberi (Yaşlıları evde tutamıyoruz,2020)

Salgının başlamasıyla uygulamaya sokulan kamusal mekân kullanımına ilişkin kısıtlama ve yasaklarla ilgili haberlere sıklıkla yansıyan bu olaylarda, erkeklerin bütün günlerini geçirdikleri sokaklardan çekilmeyi kabul edemeyişleri sadece kamusal mekânla değil, ev mekânıyla da ilişkilerine dair önemli ipuçları vermektedir. Çünkü erkeklerin yasaklara karşı gösterdikleri direncin temelinde, yaşadıkları evlere dönmekteki isteksizlikleri yatar. Haberlere konu olan birçok olayda da bunu açıç̧a dile getirdikleri gibi, toplumda yerleşmiş toplumsal cinsiyet rollerine göre, evde olmak ve bütün gün 
içerde zaman geçirmek kadınlara uygun bir davranış olarak görüldügü için salgın sürecinde zorunlu bile olsa erkeklerin sokağı terk edip evde kalmayı kabul etmesi bir hayli güç olmuştur. Hürriyet gazetesinin bir haberinde yer verilen, İstanbul Esenyurt'ta kullanılmaması için bariyerlerle çevrili banklarda oturmaya devam eden 57 yaşındaki erkeğin, zabıta ekiplerinin uyarısı karşısında "Oturmaya, hava almaya geldim. Evde kalıp çamaşır, bulaşık mı yıkayacağız?" diyerek cevap vermesi bu durumu en iyi şekilde örneklemektedir (Hürriyet, 21 Mart 2020). Yasağın bir erkek olarak kendisi için ne anlama geldiğini ifade eden bu cümle, aynı zamanda bir erkeğin gözünden evin ve evde olmanın nasıl görüldüğüne dair de ipuçları verir. Buna göre, en temelde ev işleri kadınlara özgü işler olup, ev de kadınlara ait bir mekândır; erkeklerin ise burada bir yeri ya da rolü yoktur. Buna benzer bir başka olayda, yine Esenyurt'ta yasağa uymayarak banklarda oturmaya devam eden bir erkeğin "Gidecek yer yok ne yapalım. Evde de sıkılıyorum dışarıya çıktım" diyerek yaptığı açıklama (bkz. Şekil 2) tam da bu duruma karşılık gelmektedir (Milliyet, 22 Mart 2020). Zira bir erkek olarak onun gözünde ev, nasıl vakit geçireceğini bilemediği yabancı bir mekândır. Salgında uygulanan tedbir önlemlerinin bütünüyle sarstığı da, gündelik hayatın doğal bir parçası haline gelen bu anlayış ve rutindir.

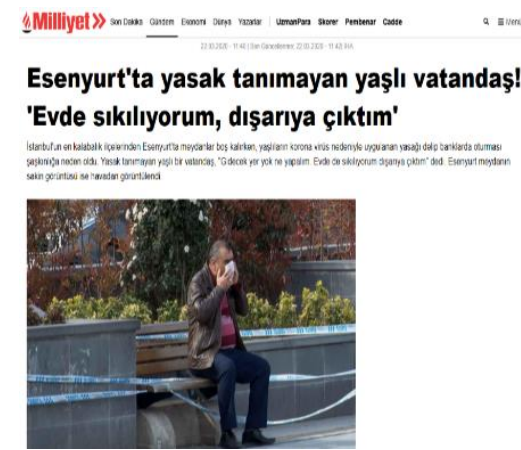

Şekil 2. Bankların kullanım yasağının ihlaliyle ilgili Milliyet Gazetesi haberi

(Esenyurt'ta yasak tanımayan, 2020)

Salgın sürecinde gündelik kamusal faaliyetleri sınırlayarak sosyal mesafe kurallarını uygulamak için getirilen kısıtlamalar sadece açı kamusal mekânlarla kalmayıp, insanların bir araya gelerek sosyalleşip vakit geçirdiği kapalı mekânları da kapsamaktadır. 19 Mart 2020'de İçişleri Bakanlığı tarafından yayınlanan genelgeyle birlikte Türkiye'de kahvehane, kıraathane, kafeterya, kır bahçesi, nargile salonu, nargile kafe gibi işletmelerin faaliyetlerinin geçici süreliğine durdurulma kararı alınmıştır (T.C. İçişleri Bakanlığı, 
2020). Köyden kasabaya ülkenin her köşesinde bulunan ve kentlerde mahalle ölçeğinden şehir merkezine kadar her yere yayılmış olan kahvehane ve kıraathanelerin kapatılması, erkeklerin evin dışında en çok vakit geçirdikleri erkek erkeğe sosyalleşme mekânını kaybetmelerine yol açmıştır. Dolayısıyla, bankların kullanım yasağında olduğu gibi, hatta ondan daha da fazla tepki ve ihlal ortaya çıkmıştır. "Toplumsal cinsiyetin kamusal alanda belirgin olarak ayrıştığı bir mekân olarak kahvehane", erkekler için sadece basitçe bir sosyalleşme alanı olmayıp, erkekliğe dair pratiklerin ve anlamların günlük yaşamın içinde üretildiği ve hayata geçirildiği bir yer işlevi görür (Arık, 2009; 177). Bu nedenle, erkeklerin genç yaşlardan itibaren gündelik hayatlarında ve ilişkilerinde büyük bir yer kaplayan bu mekândan vazgeçmeleri kolay olmamıştır. Bunun sonucunda, kahvehane ve kıraathane yasağının çeşitli şekillerde ihlal edilmesiyle ilgili çok sayıda sıra dışı olay ve görüntü haberlere konu olmuştur.

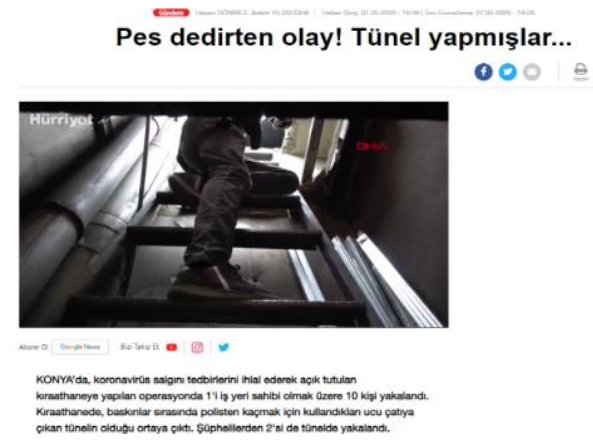

Şekil 3. Baskın yapılan kahvehaneyle ilgili Hürriyet Gazetesi haberi

(Pes dedirten olay, 2020)

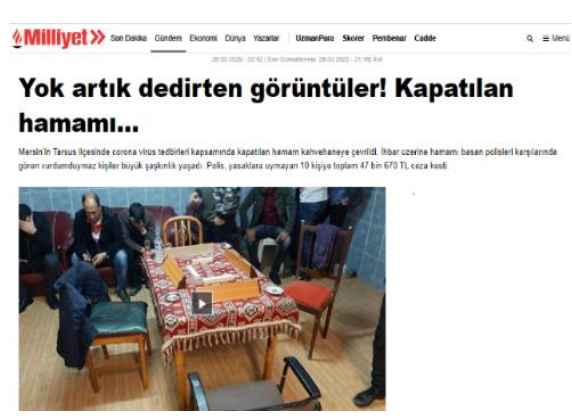

Şekil 4. Hamamın kahvehaneye çevrilmesiyle ilgili Milliyet Gazetesi haberi (Yok artık dedirten, 2020)

Yaptı̆̆ımız gazete taramasında bu konuyla ilgili ulaşmış olduğumuz 192 haber içeriğinin genelini, polis operasyonuyla yapılan baskınlar oluşturmaktadır. Kimi zaman kumar oynayanlara baskın yapıldığı şeklinde verilen bu haberlerde, ceza ödememek için ağaca çıkarak ya da camdan atlayarak kaçmaya çalışan erkeklere ilişkin bilgi ve görüntülere sıklıkla yer verilmiştir. Kahvehane ve kıraathanelerin kapatılması üzerine erkeklerin genelde iki yaygın strateji geliştirdiği gözlenmektedir. Bunlardan biri, başka mekânların ve işyerlerinin bunun için kullanılması, diğeriyse var olan mekânların yakalanmamak için gizli biçimde kullanılacak şekilde yeniden düzenlenmesidir. Gazetelere yansiya haberlerde, müdavim olan erkeklerin kimi zaman bir hir- 
davatçı dükkânını, kimi zaman da kapatılmış bir hamamı kahvehaneye çevirdikleri görülmektedir (Şekil 4). Dikkat çekmeyeceği ve yakalanma riskinin az olduğu düşünülerek seçilen bu mekânların yanı sıra, faaliyeti durdurulan kahvehanelerin yakalanma ihtimaline karşı muhtemelen çeşitli önlemler alarak gizlice kullanılması da söz konusu olmuştur (Şekil 3). Hürriyet gazetesinde "Pes dedirten olay! Tünel yapmışlar..." başlı̆̆ ile verilen habere göre, Konya' da kıraathaneye yapılan polis baskını sırasında kaçmak için kullanılan iki ucu çatıya çıkan tünelin olduğu ortaya çıkmıştır (Hürriyet, 7 Mayıs 2020). Dolayısıyla, bu örneklerde de açık bir şekilde görüleceği gibi, erkekler yakalanmayı ve para cezası ödemeyi göze alarak da olsa kahvehane mekân pratiğini sürdürmekte ısrarcıdırlar. Bunun için başka bir mekânı dönüştürmeyi ya da halihazırda var olan bir kahvehaneyi yasaklar kapsamında kullanılabilir hale getirmek için harcadıkları mesai de, erkeklerin kendilerine mal ettikleri bu kamusal mekânlardan vazgeçip eve dönmeyi kabul etmelerinin onlar için ne kadar zor olduğunu gözler önüne sermektedir.

\section{Evden Dışaruya Uzanan Kadınlar}

Salgın sürecinde kamusal faaliyetlerin özel alana taşınması ve evde kalma tedbirleri sonucunda, ev mekânı hiç olmadığı kadar gündelik hayatın merkezine yerleşmiştir. Ancak bu durum bir önceki bölümde açıkladığımız üzere erkekler için kabul etmesi oldukça zor bir durum olmuşken, kadınlar için asıl sorun evde kalmaktan çok, ev içi artan iş yükü ve bakım emeği olmuştur. Bunun temel nedeni, şüphesiz kadınların salgından önce de ev ve çevresinde daha çok vakit geçirmelerinin yanında, şehir içinde mekânsal hareketliliklerinin erkeklere göre çok daha fazla kısıtlı olmasıdır. Her ne kadar bu durum çalışan ve çalışmayanlar başta olmak üzere farklı kadınlar için değişiklik gösterse de, geleneksel toplumsal cinsiyet normlarının etkisini yoğun biçimde sürdürdüğü Türkiye toplumunda kadının yerinin evi olduğu anlayışı hala oldukça yaygındır. Ayrıca, ev içi işleri ve çocuk bakımı sorumluluğu da kadınları eve bağlamaktadır. KONDA'nın 2019 yılında gerçekleştirdiği Türkiye'de Toplumsal Cinsiyet- Hayat Tarzları Raporu'na göre, kadınların yarıya yakını hafta sonları özel bir şey yapmayıp evde kaldıklarını belirtmişlerdir. Raporda, çalışmayan kadınlar için bu oran yüzde 60'a yaklaşırken, erkeklerin ise yalnızca yüzde 39'u hafta sonlarını evde geçirmektedir (KONDA, 2019, s. 47). Dolayısıyla ev, kadınlar için salgın öncesi dönemde de erkeklere göre çok daha fazla zaman geçirdikleri ve alışık oldukları bir mekândır.

Erkekler için dışarı çıkmak ve evden ne kadar uzakta olduğu fark etmeksizin istedikleri gibi zaman geçirmek gündelik hayatlarının sorgulanamaz 
doğal bir parçasıdır. Buna karşın, kadınlar hem ataerkil kültüre bağlı olarak hem de ekonomik ve diğer nedenlerle dış dünyayla ve kamusal hayatla kısıtlı ilişkileri olması sonucunda ev çevresinde ve mahallede komşuluk ilişkileriyle sosyal ağlarını kurarak kendine özgü sosyalleşme ve mekân kullanım pratikleri geliştirmişlerdir. Bu durum, özel ve kamusal alan arasındaki sınırların birbirine karıştığ pandemi sürecinde, kadınlar ve erkeklerin evde kalma tedbirleri ve kısıtlamalar karşısında farklı sosyo-mekânsal davranışlar geliştirmelerine yol açmıştır. Buna göre, erkekler sokaklardan çekilmeye direnip kamusal mekânların kapatılmasına ilişkin yasakları ihlal etmenin yollarını ararken, kadınlar ise bu "yeni normal" in dayattığ kısıtlamalarla evin dışarıya açılan uzantılarını kamusallaştırarak ve yarı özel-yarı kamusal ara mekânlarda yeni sosyalleşme pratikleri geliştirerek baş etmeye çalışmışlardır.

Çalışmamız kapsamında hem gazete taraması hem de Twitter üzerinden yapmış olduğumuz incelemeye göre, kadınların salgının başlamasıyla birlikte hayata geçirilen kısıtlayıcı uygulamalar karşısında evin dışarıyla en açık teması olan balkonlarda çok daha fazla zaman geçirdikleri görülmektedir. Türkiye'de kadınlar için balkon gibi "ara alanlar" Covid-19 pandemisi ortaya çıkmadan önce de gündelik hayatlarında var olan ve sosyalleştikleri mekânlardır (Cantek, Ulutaş ve Çakmak, 2014). Salgın sürecinde ise balkonlar hem evde kalma tedbirlerine uyularak hem de sosyal mesafe sağlanarak dışarıda vakit geçirmek için adeta bir çıkış noktası olmuştur. İlk vakanın görüldüğü 2020 Mart ayından itibaren Twitter'da yapılan paylaşımlarda, salgın sürecinde kadınlar için balkonun hem farklı yeni işlevler kazandığı hem de balkonda olmanın anlamının değiştiği gözlenmektedir. Aşağıdaki iki ayrı kullanıcı tarafından yazılan tweet örneklerinde görüleceği üzere, balkona çıkmak zorunlu olarak evlere kapanmanın getirdiği sıkışmışlık karşısında evin dışında başka bir yerde olma ve dolayısıyla özgürleşme hissi vermektedir:

Montlarımızı giyip 5 dakika balkonda mola verdik, oradan buradan sohbet ettik. Başka bir yere gidip gelmiş gibi oldum valla. Evde 8. gün. \#EvdeKal (Öcal, 24 Mart 2020).

Annemle balkonda oturduk Türk kahvesi iciyoruzzzzz karantinada tek özgürlüğümüz balkon oldu (Menica, 13 Mayıs 2020).

Gün geçtikçe artan vaka sayıları ve alınan önlemlerle birlikte kadınların sosyalleşme mekânı olarak balkonlar giderek daha çok önem kazanmıştır. Kadınlar salgın sürecinde hava almak ve sohbet etmek için yoğun biçimde kullandıkları balkonlara, hem günlük rutinlerinde olan sosyalleşme etkinliklerini taşıyarak hem de bunlara yenilerini ekleyerek bu mekânları adeta bir 
yaşam alanına çevirmişlerdir. Kadınların salgın kısıtlamalarıyla baş etmek için evin sınırların genişletmesiyle ortaya çıan farklı gündelik sosyomekânsal pratikler hem sosyal medyaya hem de haberlere yansımıştır. Hürriyet gazetesi, Ankara'da yaşayan iki komşu kadının salgın sürecinde balkondan balkona "isim-şehir" oynayıp, türkü söyleyerek ve çay içerek vakit geçirmelerini "Balkondan balkona sosyalleşiyorlar" başlığıyla haber yapmıştır. Haberde yer verilen komşu kadınlardan birinin şu sözleri, salgınla kesintiye uğrayan rutin haline gelmiş gündelik pratiklerin balkon aracilığıyla sürdürüldüğünü ifade etmektedir: "Komşularla birbirimizin evinde her gün çay içerdik. Bu olay olunca artık balkondan balkona sohbet ediyoruz. Virüs bizi engelledi ama balkonumuzu engelleyemedi" (Hürriyet, 5 Nisan 2020).

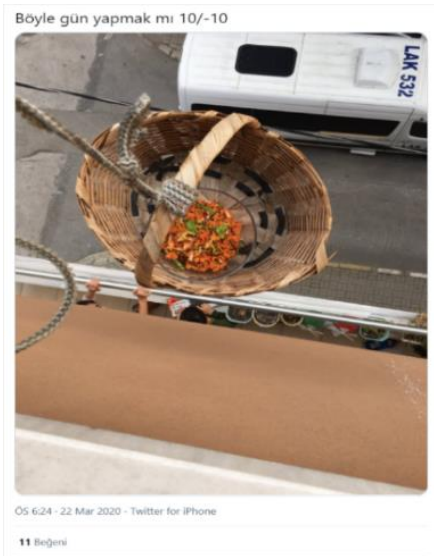

Şekil 5. Balkonda gün yapmayla ilgili Tweet Paylaşımı

(Ciğer mi bıraktınız, 22 Mart 2020)

Bu bağlamda Türkiye'de kadınların kuşaklar boyunca kendi aralarında evlerde buluşarak sürdürdükleri en yaygın sosyalleşme pratiklerinden biri olan gün yapma da (Tuncer, 2018) balkonlarda yapılmaya başlanmıştır. Çay, pasta, kısır gibi ev ikramlarının kadın günlerinin ayrılmaz parçası olması nedeniyle, bu etkinlik balkona taşınınca ortaya sıra dışı görüntüler çıkmıştır. Örneğin, Mart ayında Twitter' da komşularıyla gün yaptığını belirten bir kadın, söz konusu paylaşımına sepete konulmuş kısır tabağının alt komşuya balkondan uzatıldığını gösteren bir fotoğraf da eklemiştir (Şekil 5). Kadınların gün yapma pratiği bu süreç içerisinde yalnızca balkonlarla sınırlı kalmayıp, ayrıca pencere ya da apartman içi koridor ve kapı önü gibi ev çevresindeki yarı özel-yarı kamusal mekânlarda da devam etmiştir. Bursa'da kadınların WhatsApp grubu aracilığıyla haberleşerek evlerinin penceresinde buluşup birlikte kahve içmeleri, "Koronavirüs nedeniyle pencerelere çıkarak gün 
yaptılar" başlığıyla gazete haberine yansımıştır (Sabah, 30 Mart 2020). Benzer şekilde, kadınların sosyal mesafeyi koruyarak apartman içerisinde buluşup birlikte kahve içmeleri de Twitter' daki bir paylaşımda şu şekilde aktarılmıştır: "Suan ciddi ciddi apartmanda merdivenlerde bulustuk herkes kendi katında kahve içip muhabbet ediyoruz sjdhshshshshd" (Buse, 30 Mart 2020).

Kadınlar, salgın sürecinde arkadaşlarıyla buluşma ve misafir ağırlama gibi sosyalleşme pratiklerini de ev yerine balkon ve bahçelere taşımışlardır. Özellikle havaların ısınmasıyla birlikte, bahçesi olan evler ve apartmanlar sosyal mesafeye uyarak evin dışında sosyalleşme imkânı sağladıkları için büyük avantaj oluşturmuştur (bkz. Şekil 6). Şüphesiz kent içinde bahçeli bir evde oturmak, günümüzde toplumun çok sınırlı bir kesiminin sahip olduğu bir ayrıcalık haline gelmiş olup, bunun dışında ancak henüz kentsel dönüşüme uğramamış eski semtler ve gecekondu mahallelerinde mümkündür. Bu durum, apartmanların ortak kullanıma açk bahçelere ve yeşil alanlara sahip olmasının önemine işaret ederken, farklı sınıfsal konumlara sahip kadınların salgın tedbirleri karşısında geliştirdikleri mekânsal pratiklerin farklılaşması anlamına gelmektedir. Bahar aylarından itibaren yapılan Twitter paylaşımlarına da bunun hem sözle hem görsel olarak yansıdığı görülmektedir: "Saat 5 den beri bahçede sosyal mesafeli maskeli çay içip sohbet ettik, şimdi eve geldim, maskenin lastiklerinden kulaklarım iptal resmen 0 " (Anar, 24 Haziran 2020). Dolayısıyla bahçeli bir evde ya da apartmanda yaşayan kadınlar, salgın sürecinde maske kullanımı ve sosyal mesafe kurallarına uyarak arkadaş buluşması ve misafir ağırlama gibi gündelik sosyalleşme faaliyetleriyle bu alanları hem ev mekânı hem kamusal mekân yerine kullanmışlardır. Kadınların ev ve çevresinde salgın öncesi dönemde de erkeklere göre çok daha fazla vakit geçirmek durumunda kaldıklarını hesaba katarsak, elbette ki bu durum salgınla ortaya çıkan ve Covid-19 pandemisine özgü bir pratik değildir. Ancak burada önemli olan nokta, ev ve çevresindeki yarı özel-yarı kamusal nitelikteki bu açık alanların salgın sürecinde kullanım işlevleri çeşitlenerek artmasının yanında, eve kapanmayla birlikte bu mekânlara yüklenen anlamın da değişmiş olmasıdır. Sonuç olarak, erkekler kısıtlama ve yasaklar karşısında sokakları ve kamusal mekânları terk etmeye direnirken, kadınlar evde kalma tedbirlerinin getirdiği zorunlu sıkışmışlık haliyle ev mekânını kamusala doğru esneterek geliştirdikleri yeni mekânsal pratikler ve sosyalleşme biçimleriyle baş etmeye çalışmışlardır. 


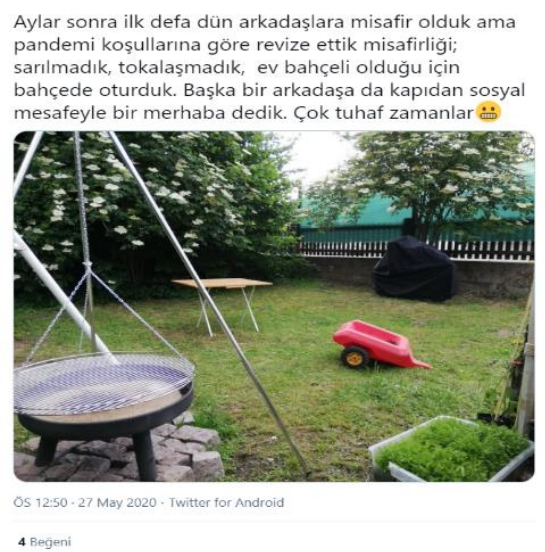

Şekil 6. Salgında bahçede sosyalleşmeyle ilgili Tweet Paylaşımı

(Crocus ancyrensis, 27 Mayıs 2020)

\section{Salgında Özelden Kamusala Erkek Şiddetinin Mekânsal Örüntüleri}

Kadınlar genel olarak vakitlerinin çoğunu ev ve çevresinde geçirmiş olsalar da, şüphesiz salgın sürecinde kısıtlamaların izin verdiği ölçüde kamusal mekânları da kullanmışlardır. Ancak günlük sosyo-mekânsal pratikleri kesintiye uğrayan erkeklerin aksine, kadınların koronavirüs ortaya çımadan önce de kamusal mekânda yaşadıkları cinsiyetlendirilmiş deneyimlerin, biçimleri ve derecelerinde farklılıklar olabilse de, sürekliliği söz konusudur. Türkiye'de konuyla ilgili yapılan çalışmaların da gösterdiği üzere, kadınların evden çıkma tercihleri ve kamusal mekân kullanımlarını etkileyen başlıca nedenlerden biri cinsel taciz ve şiddete uğrama deneyimi ya da bunun ihtimaline dair duydukları korkudur (Alkan, 2005; Lordoğlu 2018; 2016). Her ne kadar karantina ve toplumsal izolasyon uygulamalarına bağlı olarak yoğun biçimde artan ev içi erkek şiddeti salgında en hayati problemlerden biri olarak ortaya çıksa da, bu süreçte kadınların evin dışında kamusal mekanları kullanma deneyimleri de şiddetten bağımsız değildir. Pandemi öncesinde cinsel taciz ve şiddet tehlikesi barındıran sokaklar ve caddeler salgından korunmak için insanların eve çekilmesiyle birlikte issızlaşarak kadınlar için tekinsiz ve güvensiz hale gelmiştir. Kadınlar virüsten korunmak için uğraşırken, bir yandan da dışarıya çıktıkları kısıtlı sürelerde erkeklerin taciz ve takipleriyle baş etmek durumunda kalmışlardır. Şu ana kadar Covid-19 pandemisiyle ilgili Türkiye'de bu konuda herhangi bir çalışma yapılmamış olduğu için elimizde kapsamlı bir veri olmamakla birlikte, Twitter paylaşımları üzerinden yaptığımız inceleme kadınların salgın sürecinde kamusal mekânlarda yaşadıkları erkek şiddetine dair faydalı öngörüler sunmaktadır. 
Bu makalede özel olarak kamusal mekânlarda yaşanan cinsel taciz ve şiddet olaylarına odaklansak da, araştırmanın genel kapsamında salgın sürecinde erkek şiddetinin özelden kamusala uzanan mekânsal örüntülerini ortaya çıarmaya yönelik bir sosyal medya incelemesi yaptık. Buna göre taciz, takip ve şiddet gibi olayların gündelik terminolojiye yerleşmiş ifadelerinden seçtiğimiz çok sayıda anahtar kelime aracılığıyla kadınların hem evde hem kamusal mekânlarda hem de ayrıca evin dışarıyla kesiştiği kapı, pencere ve balkon gibi ara alanlarda yaşadıkları erkek şiddetine ilişkin Twitter'da yaptıkları paylaşımları toplamaya çalıştık. 1 Ocak - 31 Temmuz 2020 arasında yedi aylık süreyi kapsayan tarama sonucunda, kadınların özelden kamusala yaşadıkları cinsel taciz ve erkek şiddetini içeren toplamda 302 tweete ulaştık. Bunların 44'ü ev içi şiddet hakkındayken, 21 tanesi ise kapı eşiğinde ya da pencere ve balkonda yaşanan cinsel taciz olaylarına ilişkin aktarımlardır. Geriye kalan 237 tweet ise bu yazıda inceleyeceğimiz kadınların kamusal mekânlarda yaşadıkları cinsel taciz ve şiddet olaylarıyla ilgili paylaşımları içermektedir. Twitter'da anahtar kelimeyle manuel tarama yaparak toplam verinin sınırlı bir oranına ulaşılabildiği için, elbette ki bu rakamlar üzerinden geniş çıarımlarda bulunmak doğru olmayacaktır. Ancak yine de elde edilen tweetlerin temalara göre sayısal dağılımında, belli eğilimlerin ortaya çıtığı görülebilir. Bu anlamda, Twitter' da paylaşım yapan kadınların ev içinde uğradıkları şiddetten ziyade kamusal mekânlarda yaşadıkları cinsel taciz ve şiddet olaylarını çok daha fazla anlatma eğiliminde olduklarını söyleyebiliriz. Bu durum, kadınların birlikte oldukları ya da aile içindeki erkeklerden gördükleri şiddete kıyasla, sokakta tanımadıkları erkeklerin yaptığı cinsel taciz ve şiddeti daha rahat ve korkmadan anlatabiliyor olmalarından kaynaklanması muhtemeldir.

Yaptığımız taramanın bir diğer sonucu ise, kadınların tanımadıkları erkeklerden gördükleri cinsel tacizle karşılaşmalarının sadece evin dışındaki açık ya da kapalı kamusal mekânlarla sınırlı olmayıp, evin dışarıya açıldığı alanlarda da bu tür olayları yaşama ihtimallerinin olmasıdır. Twitter'da yapılan paylaşımlarda pencere önünde ya da balkonda otururken sokaktan bir erkeğin izlemesi ya da cinsel organının teşhiri gibi olaylara rastlanmakla birlikte, bu konuda özellikle teslimat için kapıya gelen kargo ve kurye çalışanlarıyla yaşanan taciz olayları öne çıkmaktadır. Bu durum genelde kargo/kurye elemanının teslimatı yaptıktan sonra, kapıda gördüğü kadına Whatsapp ya da Instagram gibi uygulamalardan ulaşmasıyla dijital şiddet şeklinde gerçekleşmektedir. Daha çok genç, yalnız yaşayan kadınlar tarafından Twitter'da bu konuda yapılan paylaşımlarda, özellikle kargo/kurye elemanlarının ev ad- 
resini bilmelerinin tedirginlik yarattı̆gı ve bundan dolayı evde tek başına güvende hissetmediklerine ilişkin ifadeler dikkat çekmektedir. Pandemi sürecinde internetten alışveriş yapma ve sipariş vermenin artmasına bağlı olarak, kargo/kurye ve sipariş elemanlarının çoğunluğunun erkek olması nedeniyle, bu tür taciz olaylarında da bir artış beklenebilir ancak biz aylık tarama sonucu elde ettiğimiz verilerde böyle bir durum tespit etmedik. Bunun yerine, salgin öncesinde de Twitter'a yansiyan bu tür taciz şikâyetlerinin, salgınla birlikte devam ettiğini söyleyebiliriz. Sonuç olarak, bu konuda her ne kadar kesin çkarım yapmak için elimizde yeterli veri olmasa da, bu örneklerin ev ile dışarısının kesiştiği balkon, pencere ve kapı gibi yarı özel-yarı kamusal alanların kadınlar için birlikte vakit geçirme, sosyalleşme ve özgürleşme imkânı sağladığı gibi, yalnızken cinsel taciz ve şiddet ihtimalini de barındırabileceğini göstermesi açısından önemli olduğunu düşünüyoruz.

\section{Issızlaşan Sokaklar ve Kadınların Çifte Güvenlik Mesaisi}

Araştırmamız kapsamında kadınların gündelik kamusal mekânlarda yaşadıkları cinsel taciz ve şiddet olaylarıyla ilgili çok sayıda Twitter paylaşımına ulaştığımız gibi, bunlar olayın yaşandığı mekâna, şiddetin biçimine ve kişisel deneyim ya da tanıklık olmasına bağlı olarak epeyce çeşitlilik göstermiştir. Buna göre, tarama sonucunda ulaştığımız toplam 237 tweet'in arasında, kadınların kamusal mekânlarda tanıdıkları erkeklerden gördükleri (4 tane) ya da tanık oldukları başka bir kadına yanındaki erkek tarafında yapılan (18 tane) şiddet olaylarına ilişkin aktarımlar da bulunmaktadır. Ancak atılan tweet'lerin çoğunluğunun içeriğini, tartışmamız açısından da konuyla doğrudan ilgili olan, sokakta ya da toplu taşımada yaşanan cinsel taciz ve takip olayları oluşturmuştur. Bu bağlamda ulaşabildiğimiz kadarıyla, kadınların erkekler tarafından sokakta yürürken sözlü taciz ya da yürünerek takip edilmesi üzerine toplamda 121 tane, araçla takip edilmesiyle ilgiliyse 49 tane tweet atılmış olması dikkat çekicidir. Bunlara ek olarak, toplu taşıma araçlarında (23 tweet) ve kafe ya da parklarda (7 tweet) yaşanan taciz olaylarına ilişkin paylaşımlar bulunsa da, sayıca az oldukları için bu bölümde yaygın bir pratik olarak karşımıza çıkan sokaktaki cinsel taciz ve takip olayları üzerinden salgın sürecinde kadınların kamusal mekân deneyimlerini ele alacağız.

Twitter incelemesinde ortaya çlkan sonuçların en önemli noktalarından biri, kadınların salgın öncesi günlük hayatlarındaki kamusal mekân deneyimlerinin Covid-19 pandemisinin yol açtığı olağanüstü süreçte de devam etmiş olmasıdır. Kadınların sokakta yürürken erkeklerin tacizine uğraması ve onlar tarafından takip edilmesi, Türkiye'de (ve birçok ülkede) eskiden beri 
var olagelen ve onların kamusal mekândan kadın olarak dışlanma deneyimlerinin en belirgin göstergelerinden biridir (bkz. Tuncer, 2018). Ancak hem zorunlu kısitlamalar hem de virüsten korunmak için genel olarak evin d1şında çok sınırlı zaman geçirilmesine rağmen, salgın sürecinde de bu durumun, azalmak yerine, kadınların günlük hayatlarını zorlaştırmaya devam ettiği gözlenmektedir. Twitter'da yapılan paylaşımlara göre, salgının başlamasından itibaren kadınlar alışveriş yapmak gibi ihtiyaçlar için kısa süreliğine dışarıya çıtıklarında bile, erkekler tarafından hem yürüyerek hem de araç ile takip edilmişlerdir. Aşağıdaki örneklerde de görüleceği üzere, kısa süreli çarşı ya da market ziyaretlerinde bile kadınlar birden fazla kez tacize uğrayabilmektedir:

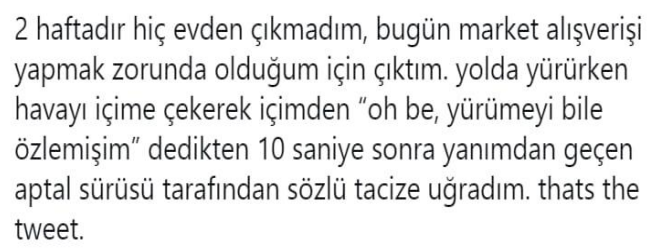

ÖS 6:39 28 Mar 2020 - Twitter for iPhone

3 Beğeni

Şekil 7. Sözlü tacizle ilgili Tweet Paylaşımı

(Such a gabe itch, 28 Mart 2020)

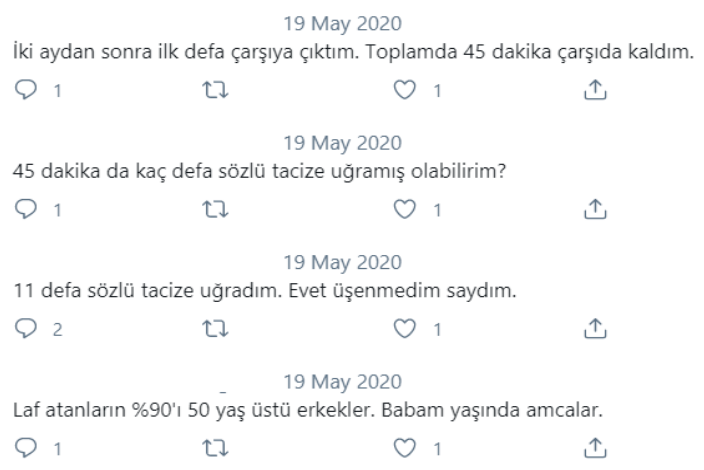

Şekil 8. Sözlü tacizle ilgili Tweet Paylaşımı (Matruşka, 19 Mayıs 2020)

$\mathrm{Bu}$ iki Twitter paylaşımında ortaklaşan bir diğer nokta ise, kadınların uzun süre tedbir kısıtlamaları gereğince evde kaldıktan sonra, ilk dışarı çıktıkları anda erkeklerin tacizleriyle karşılaşıyor olmalarıdır. Üstteki ilk alıntıda 
(Şekil 7), "oh be, yürümeyi bile özlemişim" ifadesiyle açıkça dile getirilen, salgında uzun süre evde kapalı kalmanın ardından dışarıda olmanın verdiği mutluluk, kadınlar için kısıtlı zamanda içerisinde bile çok uzun sürmeyip tacizle gölgelenmektedir. Salgından korunmak ve virüsün yayılmasını engellemek için uygulanan önlemler, şüphesiz sadece ev dışında geçirilen zamanı değil, mekânsal hareketliliği de zorunlu olarak kısıtlamıştır. Eğer bu süreçte işe gidip gelmiyorlarsa, insanlar genelde zorunlu durumlar dışında vakitlerinin çoğunu ev ve mahalle çevresinde geçirmektedirler. Dolayısıyla kadınların Twitter'da paylaştıkları taciz ve takip olayları salgın boyunca sadece kısıtlı bir zaman içerisinde değil, aynı zamanda sınırlı bir mekânsal hareketliliğe rağmen gerçekleşmiştir. Örneklerde görüleceği üzere, kadınlar evden uzaklaşmadan sigara içmeye çıtıklarında ya da yakındaki bir markete gidip gelirken bile yürüyerek veya araçla takip edilebilmektedirler.

17 Haz 2020

Şu an gerçekleşen olayı anlatıyorum, evimden 100 metre ileride olan markete giderken ve dönerken araba ile takip edildim. Kafanıza soksanız iyi olur bunun hiç bir açıklanabilir tarafi yok sizi savunanlara yine de cevap vereyim, açık giyinmemiştim, dar giyinmemiştim, makyaj bile..

17 Haz 202015
Yapmamıştım. Hatta maske taktığım için yüzümün yarısı bile görünmüyordu.
Bu bir taciz ve bu korkuyu bana yaşatma hakkınız yok!
0

Şekil 9. Ev çevresinde tacizle ilgili Tweet Paylaşımı (Lisztomania, 17 Haziran 2020)

KADINLAR VE KIZLAR Karantinada lütfen daha çok dikkat edin hava almaya çıkarken. Kapımın hemen ilerisinde yeğenlerime kötü örnek olmamak için sigara içmeye çıktım 5 dklık. sapığın biri tarafından takip edildim. Etraf sessiz ve az sayıda insan olduğu için şerefsizlere gündoğuyor

ÖÖ 2:56 - 25 Nis $2020 \cdot$ Twitter for Android

7 Beğeni

Şekil 10. Ev çevresinde tacizle ilgili Tweet Paylaşımı (Just the cigarette, 25 Nisan 2020)

Farklı kullanıcılar tarafından yapılan bu iki paylaşımda da yaşanılan taciz olayına karşı duyulan korku ve öfke ifade edilirken, salgın koşullarına da yer verilmiştir. Üstteki iki tweet'lik paylaşımda (Şekil 9) dile getirilen maske ta- 
kılmasından dolayı yüzünün görünmemesine rağmen tacize uğranması, kadın bedeninin kamusaldaki varlığının hiçbir koşulda erkek bakışı ve şiddetinden azade olamadığını göstermektedir. Salgın zamanında bile kadınlar virüsten korunmaya çalışırken bir yandan da erkek tacizi ve şiddetiyle uğraşmak zorunda bırakılmışlardır. Kadınları sokağa çıkarken dikkatli olmaları için uyaran diğer örnek paylaşımda ise, salgınla birlikte sokakların ıssızlaşmasının erkek şiddetine zemin hazırladığına işaret etmektedir.

İnsanların evlere çekilmesi sonucunda sokakların ıssızlaşması, salgının kamusal mekânlara yansıyan en belirgin sonuçlarından biri olup, kadınların kamusal mekân deneyimlerine ilişkin Twitter paylaşımlarına da sıklıkla yansımıştır. Dışarıda az sayıda insanın olması, salgın sürecinde kadınları daha tedirgin ve güvensiz hissettirmiştir. Çünkü herhangi bir tehlike anında veya şiddet olasılığına karşı sokakta yardım edebilecek bir başkasının bulunması kadınların kendilerini daha güvende hissetmelerine neden olur (Acuner, 2016). Koronavirüsle ortaya çlkan bu durum, salgın sürecinde kadınların kamusal mekânlarda güvenliği açısından bir paradoks yaratmıştır. İnsanların az olduğu tenha bir sokak bir yandan virüse maruz kalmamak yönünden güvenli hale gelirken, bir yandan da kadınların cinsel taciz ve şiddete uğrama riski nedeniyle daha güvensiz hissettikleri bir yere dönüşmüştür. Bu çifte tehlike halini, her gün işe gidip gelmek zorunda olan sağlık çalışanı kadınlardan biri Twitter'da şöyle aktarmıştır: "Bende bir sağlık çalışanıyım ve özellikle akşam nöbetine giderken ya da akşam işten çıkarken heryerin karanlık ve 1ssız olmasından dolayı çok tedirginim 2 kere yanımdan geçen arabalar tarafundan taciz edildim kendimi koronadan ve tacizden nasıl koruyacam bilmiyorum. \#vaka18135" (Yüksel, 2 Nisan 2020).

Büyük çoğunluğunu kadınların oluşturduğu sağlık çalışanları, dünyanın birçok yerinde olduğu gibi Türkiye' de de bu süreçte artan iş yükü nedeniyle çok daha zorlu ve ağır koşullarla mücadele etmek zorunda kalırken, bir de üstüne uzayan mesailerin ardından eve dönerken iyice tenhalaşan sokaklarda cinsel taciz ve şiddet tehlikesiyle baş etmek durumunda kalmışlardır. Şüphesiz kent sokaklarının salgında giderek daha tekinsiz hale gelmesinin yarattığı korku sadece sağlık sektöründe çalışan kadınlarla sınırlı olmayıp, başta kilit sektörlerdekiler olmak üzere, evden çalışma imkânı olmayan ve düzenli işe gidip gelmek zorunda kalan tüm kadınlar için geçerlidir. Bu konuyla ilgili yapılan Twitter paylaşımlarından biri, salgında virüs bulaşma korkusuna ek olarak cinsel şiddete uğrama korkusunun kadınların hayatlarını ne kadar derinden etkilediğini gözler önüne serer: "geçen işten gelirken 
biri takip etti bi markete girip yardım istedim takip edeni parmağımla gösterdim market çalışanı eve kadar bıraktı, rüyamda tecavüze uğruyodum,2 kez sokakta yürürken gölgemden korktum kalbim küt küt attı:( bunları yaşatanların hesap vereceği günler de gelicek" (G., 21 Temmuz 2020). Bu örnekte de açıkça ifade edildiği gibi, kadınların yaşadıkları cinsel şiddete uğrama korkusu sadece kamusal mekânda bulundukları anla sinırlı kalmayıp sonrasinda da devam eder. Bu durum, ister gerçek bir deneyime dayansın ister varsayımsal olsun, kadınların tüm bedensel davranışlarını ve mekânsal pratiklerini etkiler. Bu nedenle, kadınlar sokaktayken bir taciz ya da saldırı ihtimaline karşı her an tetikte olmak zorunda kalırken, aynı zamanda bunun olmasını engellemek ve kendilerini korumak için sürekli davranışlarını değiştirip ayarlamaya çalışmakla uğraşırlar. Kadınların omuzlarına ağır bir yük bindiren bu durum, salgın öncesinde olduğu gibi salgın sürecinde de kadınların günlük kamusal mekân deneyimlerinde belirleyici olmayı sürdürmüştür. Kelly'nin tanımlamasıyla bu "güvende olma mesaisi"nin kadınlar üzerinde nasıl bir baskı ve engellenme yarattığı, Twitter'da yapılan bir paylaşımda son derece açı ve etkileyici bir ifadeyle ortaya koyulmuştur:

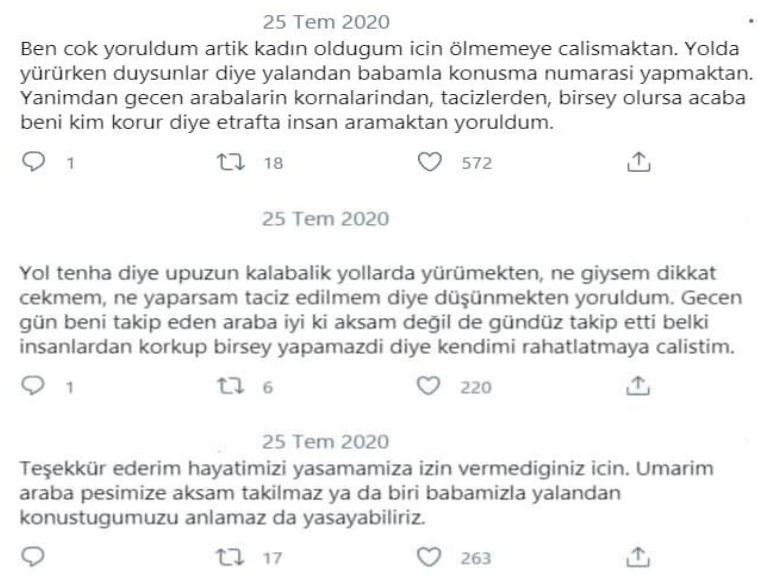

Şekil 11. Kadınların güvenlik mesaisiyle ilgili Tweet paylaşımı

(Cakici, 25 Temmuz 2021)

Bu örnekte görüldüğü üzere, kadınlar daha evden dışarı çıkmadan önce tacizden kaçınmak için giyeceği kıyafetleri ve davranışları hesap etmekte olup, sokaktayken de cinsel taciz ve saldırıya uğrama ihtimaline karşı kendilerini korumak ya da böyle bir durumun yaşanmasını engellemek için sürekli bir taktik ve strateji geliştirmekle uğraşırlar. Bu paylaşımda ifade edilen sözlerin dikkat çekici noktası ise, kadınların bu mesaiyi her dışarı çıtıklarında 
güvende ve hayatta kalmak için sürdürmek zorunda olmalarıdır. Diğer bir deyişle, gündelik hayatın olağan akışı içinde göze görünmeyen bu uğraş kadınlar için nihayetinde ölüm kalım meselesidir. Bu durum, Covid-19 gibi öldürücü olabilecek bir virüsün bulaşma riski olduğu pandemide hem virüse yakalanma korkusu hem de çok sayıda kısıtlama ve yasağa uyma zorunluluğuyla birlikte düşünüldüğünde, kadınların hali hazırdaki günlük mesaisinin salgında katlanarak nasıl artmış olabileceğini tahmin etmek zor değildir. Bir yandan virüsün bulaşmasından kaçınmaya çalışırken, bir yandan salgınla birlikte issızlaşan sokaklarda kadın olarak şiddete uğramadan eve dönebilmek, kadınlar için pandemide adeta çifte güvenlik mesaisi olmuştur. Dolayısıyla, erkeklerden farklı olarak, kadınların salgın sürecinde sokaklar başta olmak üzere gündelik kent kamusal mekân deneyimleri birden çok nedenle k1stllanip engellenmiştir.

\section{Sonuç}

Bu çalışmada, bütün dünyada toplumsal hayatın geleneksel örgütlenmesini temelden sarsarak olağan yaşama pratiklerini kesintiye uğratan Covid-19 pandemisinin toplumsal cinsiyet ve mekân ilişkisi bakımından etkilerini, Türkiye'de salgın nedeniyle değişen gündelik kamusal mekân deneyimlerine odaklanarak inceledik. Özel ile kamusal arasındaki geleneksel sınırların hem mekânsal hem toplumsal olarak son derece cinsiyetlendirilmiş olduğu varsayımından yola çıkarak, salgın tedbirleri kapsamında kamusal mekânı ve yaşamı kısıtlayan düzenlemelerin ve yasakların gündelik hayatın sürdürülmesinde kadınlar ve erkekler için nasıl farklı etki ve sonuçlar yarattığını ortaya çıkarmaya çalıştık. Araştırma kapsamında yaptığımız sosyal medya incelemesi ve gazete taramasının sonuçlarına göre, kamusal mekân deneyimleri cinsiyetlendirilmiş pratikler etrafında belirlendiği ve şekillendiği için, salgında kentsel alanlar ve mekânların kullanımına ilişkin kısıtlama ve yasaklara verilen tepkiler kadınlar ve erkekler arasında büyük bir farklılaşma göstermiştir. Buna göre erkeklerin, özellikle de belli bir yaş üstünde olup çalışmayanların, günlerinin büyük bir kısmını geçirdikleri ve sosyalleştikleri sokakları ve kahvehane/kıraathane gibi kamusal mekânları terk etmeye yanaşmamaları dikkat çekicidir. Bu durum, kamusal mekân kısıtlamalarına yönelik erkekler tarafından yapılan çok sayıda ihlalin gazete haberlerine konu olmasında çarpıcı bir biçimde görülebilir. Buna karşın, kadınlar çoğunlukla salgından önce de günlük hayatlarında önemli bir yer işgal eden balkon, pencere ve bahçe gibi evin dışarıya açılan ara alanlarında yeni mekânsal pratikler 
ve sosyalleşme biçimleri geliştirerek kısıtlama ve yasaklarla baş etmeye çalışmışlardır. Pandemi kriziyle mekânsal davranışlarda ortaya çıkan bu farklılaşma, salgından önceki "normal"de kentsel mekânın ve gündelik hayatın özel-kamusal ayrımına dayalı toplumsal cinsiyet ideolojisine göre düzenlenmiş olduğunun göstergesidir. Dolayısıyla salgının başlamasıyla kamusal mekânda uygulanan kısıtlamalarla günlük hayatı ve alışageldiği pratikleri asıl kesintiye uğrayan erkekler olmuştur. Ataerkil cinsiyet kültürüne bağlı olarak kadınların kısitlamalar ve engeller etrafında deneyimledikleri kamusal mekânlarda, erkekler bugüne dek özgürce istedikleri gibi dolaşmaları sebebiyle, salgınla birlikte aniden hayatlarına giren kısıtlamalar karşısında afallayarak bunlara karşı koymuşlardır. Bu durum, toplumda halihazırda yerleşmiş ve her alanda etkisini gösteren cinsiyet temelli eşitsizliklerin pandemiyle birlikte değişen kamusal mekan deneyimindeki bir tezahürü olup, kentsel mekanın ve yaşamın kadınların aleyhine olacak şekilde cinsiyetlendirilmiş olduğunu ortaya koyar.

Bu çalışmanın da dayandığı feminist coğrafya ve planlama çalışmaları, kadınların kent hayatında erkeklere göre eşitsiz ve dezavantajlı konumunu, kentlerin toplumsal cinsiyete dayalı özel-kamusal ayrımına göre düzenlenmesiyle açıklamışlardır. Günümüz kentlerinde bu durum hem cinsiyet körü tasarım ve planlamalar hem de ataerkil toplumsal cinsiyet normları ve kültürel pratikler dolayısıyla devam etmekte olup, pandemi gibi küresel bir krizin yarattığı eşitsizliklerle daha da derinleşmiştir. Salgın koşulları bir yandan kadınların ev içindeki şiddete karşı daha da korunaksız hale getirirken bir yandan da kamusal mekânla var olagelen sınırlı ve gerilimli ilişkilerini pekiştirmiştir. Bu anlamda, erkeklerin aksine, kadınların salgın öncesindeki gündelik kamusal mekân deneyimleri büyük bir kesintiye uğramadan devam etmiştir. Bu süreklilik, kadınların sadece kamusal mekânlara kısıtlı erişimleriyle sınırlı olmayıp, kent sokakları başta olmak üzere bu mekânlarda cinsel şiddete uğrama deneyimi ve korkusu için de geçerlidir. Araştırma kapsamında yaptığ1miz sosyal medya incelemesi sonuçları, salgın sürecinde hem zorunlu kısıtlamalar hem de virüsten korunmak için evin dışında çok sınırlı zaman geçirilmesine rağmen kadınların kamusal mekânlarda uğradığı cinsel taciz ve şiddetin günlük hayatlarını zorlaştırmaya devam ettiğini göstermektedir. İnsanların evlere çekilmesiyle sokakların ıssızlaşması ise etrafta yardım isteyecek birinin de olmaması nedeniyle, kadınların salgın döneminde dışarıya çıktıklarında daha tedirgin ve güvensiz hissetmesine neden olmaktadır. Bunun sonucunda, kadınlar kamusal mekânları kullanırken aynı anda hem virüse yakalanma hem de erkek şiddeti tehlikesiyle karşı karşıya kalmışlardır. Bu çifte 
tehlike durumu, kadınların mekânsal pratiklerini ve hareket özgürlüklerini sınırlamakla kalmayıp, kamusal mekânlarda güvenli olmak için harcadıkları mesaiyi de ikiye katlamıştır. Dolayısıyla salgınla birlikte büyük bir artış göstermesi nedeniyle gölge pandemi olarak ilan edilen toplumsal cinsiyet temelli şiddet, kadınların hayatını ve güvenliğini sadece özel alanda değil kamusal mekânlarda da tehdit etmektedir. En temelde güvenli bir yaşam hakkını ihlal eden bu durum, pandemide kadınların özelden kamusala gündelik pratiklerinde kent haklarının engellenmesi anlamına gelmektedir.

Araştırmada elde edilen bu sonuçlar, bir yandan Covid-19 pandemisinin mekânsal etkilerinde toplumsal cinsiyetin belirleyici olduğunu bir yandan da toplumsal cinsiyete dayalı eşitsizliklerin meydana gelmesinde mekânın etkin bir rolü olduğunu göstermektedir. Bu ikisinin kesişiminde pandemi koşullarının gündelik kent kamusal mekân deneyimlerini nasıl dönüştürdügüne bakmak, ayn zamanda kent hakkını toplumsal cinsiyet perspektifinden yeniden düşünme gerekliliğini de beraberinde getirir. Bu bağlamda, kadınların ve erkeklerin kent hakkından eşit biçimde yararlanarak kamusal mekânlara sınırsız erişimlerinin ve bu mekânları özgürce, güvenli bir şekilde kullanabilmelerinin nasıl sağlanacağı sorusu hem devam eden pandemi krizinin yönetimi hem de pandemi sonrası kentlerin geleceği açısından önem kazanmaktadır. Sosyal medya ve gazete haberlerinin incelenmesine dayanarak elde ettiğimiz sonuçlar, bu soruyla ilgili önemli öngörüler sağlamakla birlikte bu konuda daha kapsamlı ve derinlemesine araştırmaların yürütülmesi ihtiyacına ışık tutmaktadır. 


\title{
Extended Abstract
}

\section{Covid-19 Pandemic Across the Public-Private Division: Gendered Everyday Urban Experience and Women's Safety Work}

\author{
* \\ Selda Tuncer \\ Rabia Demirci \\ ORCID: 0000-0002-4657-6334 \\ ORCID: 0000-0001-8423-1495
}

The impacts of a wide range of restrictions and cautionary measures that have substantially transformed public space during the pandemic process on urban space and standard of living are of great importance because the accessibility and use of public space directly affects the right to the city, as it is closely associated with meeting basic needs and accessing resources and services (Mitchell, 2003). However, for the most part of the reports and evaluations published in reference to these issues, although attention is drawn to urban disparity and poverty which had been exacerbated due to the pandemic within the context of class and race, it is observed that the gender dimension is confined to certain issues and is austerely ignored particularly throughout discussions concerning urban public spaces.

In this study, we examined the impacts of the Covid-19 pandemic, which shook the conventional organization of social life all over the world to its foundations and interrupted regular everyday life practices, in terms of gender and space relations, by focusing on the daily experiences of public spaces that changed due to the pandemic in Turkey. Based on the assumption that the traditional boundaries between private and public dichotomy are extremely gendered both in terms of spatial and social dimensions, we attempted to reveal how the regulations and prohibitions that restrict public space activities and daily life practices within the scope of epidemic measures 
indeed have different effects and consequences for women and men concerning the sustainability of daily life. The findings of the social media and newspaper data show that the reactions set against the prohibition and restrictions on the use of urban areas and public spaces during the epidemic have varied widely across women and men since the experiences of public spaces are determined and shaped on the ground of gendered practices. According to said conclusions, it is noteworthy that men, especially elderly men over a certain age who are retired or do not work are not easily persuaded thus they do not refrain from circulating outside on the streets and going to public venues such as coffee houses where they spend most of the day socializing with each other. This situation can be seen conspicuously in wide media coverage as numerous violations of prohibition and restrictions perpetrated by men appear in the news.

On the other hand, we observed that women generally tried to cope with prohibition and restrictions by developing new spatial practices and forms of socialization in the outwards yet intermediate areas in the vicinity of the house, such as balconies, windows and gardens, which occupied an important place in their daily lives even before the pandemic. This differentiation, which emerged in spatial behaviours with the pandemic crisis, is an indication that during the "normal" prior to the pandemic crisis, urban space and daily life were arranged according to the gender ideology based on the private-public dichotomy. Therefore, no sooner than the outbreak of the pandemic, daily life and regular practices of men were interrupted by the restrictions enforced in the public space. Due to the patriarchal gender culture, in public spaces where women regularly experience restrictions and barriers, men have been stunned by the restrictions that they have suddenly encountered because of the pandemic as they used to freely move around at their ease. This particular circumstance is a manifestation of the gender-based inequalities which are already established in society and exert an influence on each field during the changing public spatial experience on the occasion of the pandemic, and reveals that urban space and life are gendered to the detriment of women.

Feminist geography and urban planning studies have elucidated the unequal and disadvantaged position of women in urban life compared to men, by arranging cities according to the gender-based private-public dichotomy. In today's cities, this state of affairs continues incidental to both gender-blind design and planning, patriarchal gender norms and cultural practices, and has been deepened due to the inequalities created by a global crisis such as a pandemic. While the epidemic conditions made women more vulnerable to domestic violence, they also reinforced women's existing limited and tense 
relations with the public space. In this sense, contrary to men, women's prepandemic daily experiences of public spaces continued without being interrupted. This continuity is not limited to women's restricted access to public spaces but also applies to the experience and fear of sexual violence likely to occur in these spaces, particularly on city streets. The conclusions of the social media analysis we conducted within the scope of the research reveal that sexual harassment and violence against women in public spaces continues to complicate their daily lives, despite the mandatory restrictions and quite limited time spent outside the home to protect themselves from the virus during the epidemic. The desolateness of the streets due to the lockdown of people inside their homes causes women to feel more uneasy and insecure when they go out during the pandemic period since there is no one around to ask for help when needed. As a consequence, women faced the danger of both contracting the virus and gender-based male violence while using public spaces. This dual insecure state of distress does not only restrict women's spatial practices and freedom of movement but also doubled the time women spent to feel safe and secure in public spaces. Therefore, gender-based violence, which was declared as a shadow pandemic due to its heavily intensified frequency incidental to the pandemic threatens the life and safety of women not only in the private sphere, but also in public spaces. When considering these circumstances which fundamentally violate the right to a safe life connotes that women's right to the city is restrained throughout their daily life practices starting from the private sphere to public spaces during the pandemic.

\section{Kaynakça/References}

Acuner, D. (2016). Canavarlaştırılan kent sokakları: Kadının kent deneyimi üzerine $\begin{array}{lllll}\text { bir değerlendirme. } \quad F e \quad \text { Dergisi, } & 8 & \text { (1), } & \text { 1-14. }\end{array}$ https://doi.org/10.1501/Fe0001_0000000148.

Alkan, A. (2005). Yerel yönetimler ve cinsiyet: Kadinlarm kentte görünmez varlı̆̆l, Ankara: Dipnot Yayınevi.

Alteri, L., Parks, L., Raffini, L. ve T. Vitale. (2020). Covid-19 and the structural crisis of liberal democracies. Determinants and consequences of the governance of pan$\begin{array}{lllll}\text { demic. Partecipazione } e \text { Conflitto, } 14 & \text { (1), } & \text { 1-37. }\end{array}$ https://doi.org/10.1285/i20356609v14i1p01.

Anar, R. E. [@rabia_anar]. (2020, 24 Haziran). Saat 5 den beri bahçede sosyal mesafeli maskeli çay içip sohbet ettik, şimdi eve geldim, maskenin lastiklerinden kulaklarım iptal resmen $\theta$. [Tweet]. Erişim adresi: https://twitter.com/rabia_anar/status/1275862527264591873?s=20. 
Ancyrensis, C. [@crocusancyrenss]. (2020, 27 Mayis). Aylar sonra ilk defa dün arkadaşlara misafir olduk ama pandemi koşullarına göre revize ettik misafirliği; sarılmadık, tokalaşmadık, ev bahçeli olduğu için bahçede oturduk. Başka bir arkadaşa da kapıdan sosyal mesafeyle bir merhaba dedik. Çok tuhaf zamanlar: ${ }^{2}$. [Tweet]. Erişim adresi: https://twitter.com/crocusancyrenss/status $/ 1265581112606236673$ ?s=20.

Arık, H. (2009). Kahvehanede erkek olmak: Kamusal alanda erkek egemenliğin antropolojisi. A. Alkan (Der.), Cins cins mekân içinde (ss. 168-202). İstanbul: Varlık Yayınları.

Azcona, G., Bhatt, A., Encarnacion, J., Plazaola-Castaño, J., Seck, P., Staab, S. ve Turquet, L. (2020). İçörüden aksiyona: Covid-19 döneminde toplumsal cinsiyet eşitliği. BM Kadın Birimi. 10 Ocak 2021 tarihinde https://data.unwomen.org/publications/insights-action-gender-equality-wake-covid-19 adresinden erişildi.

Bayar, A., Günçavdı, Ö. ve Levent, H. (2020). Covid-19 salgınının kadınların çalışma ve hane yaşamı üzerine etkileri. İstanPol. 15 Ocak 2021 tarihinde https://d4b693e1c592-4336-bc6a-36c134d6fb5e.file-

susr.com/ugd/c80586_86b8dec8fdba4de6afbe1bf1136fa068.pdf adresinden erişildi.

BM Kadın Birimi. (2020a). Violence against women and girls: The shadow pandemic. 15 Ocak 2021 tarihinde https://www.unwomen.org/en/news/stories/2020/4/statement-ed-phumzile-violence-against-women-during-pandemic adresinden erişildi.

BM Kadın Birimi. (2020b). Covid-19 and ensuring safe cities and safe public spaces for women and girls. 18 Ocak 2021 tarihinde https://www.unwomen.org/en/digital-library/publications/2020/05/brief-covid-19-and-ensuring-safe-cities-andsafe-public-spaces-for-women-and-girls adresinden erişildi.

Bows, H. ve Fileborn, B. (2020) Space, place and GBV, Journal of Gender-Based Violence, 4 (3), 299-307. https://doi.org/10.1332/239868020X15983760944114.

Buse. [@buseeblbn]. (2020, 25 Mart). Suan ciddi ciddi apartmanda merdivenlerde bulustuk herkes kendi katında kahve içip muhabbet ediyoruz sjdhshshshshd. [Tweet]. Erişim adresi: https://twitter.com/buseeblbn/status/1244638936498143233?s=20.

Cakici, S. [turanjpic]. (2020, 25 Temmuz). Ben cok yoruldum artik kadın oldugum icin ölmemeye calismaktan. Yolda yürürken duysunlar diye yalandan babamla konusma numarasi yapmaktan. Yanimdan gecen arabalarin kornalarindan, tacizlerden, birsey olursa acaba beni kim korur diye etrafta insan aramaktan yoruldum. [Tweet]. Erişim adresi: https://twitter.com/turanjpic/status/1286795401241255936?s=20.

Cantek, F. Ş., Ulutaş, Ç. Ü. ve Çakmak, Ş. (2014). Evin içindeki sokak, sokağın içindeki ev: Kamusal ile özel 'ara'sında kalanlar. F. Ş. Cantek (Der.), Kenarın kitabı: 'Ara'da kalmak, çeperde yaşamak içinde (ss. 121-159). İstanbul: İletişim. 
Çomu, T. ve Halaiqua, İ. (2015). Web içeriklerinin metin temelli çözümlenmesi. M. Binark (Ed.). Yeni medya çalışmalarında araştırma yöntem ve teknikleri içinde (ss. 26-88). İstanbul: Ayrıntı Yayınları.

Demertzis, N. ve Eyerman, R. (2020). Covid-19 as cultural trauma. American Journal of Cultural Sociology, 8, 428-450. https://doi.org/10.1057/s41290-020-00112-z

Devine-Wright, P., Pinto de Carvalho, L., Di Masso, A., Lewicka, M., Manzo, L. ve Williams, D. (2020). "Re-placed" - reconsidering relationships with place and lessons from a pandemic. Journal of Environmental Psychology, 72, 1-8. https://doi.org/10.1016/j.jenvp.2020.101514.

Domosh, M. (1998). Geography and gender: home, again?. Progress in Human Geography, 22 (2), 276-282. https://doi.org/10.1191/030913298676121192.

Duncan, N. (1996). Renegotiating gender and sexuality in public and private spaces. in N. Duncan (Ed.), BodySpace: Destabilizing Geographies of Gender and Sexuality içinde (ss. 127-45), London and New York: Routledge.

Ergönen, A.T., Biçen, E. ve Ersoy, G. (2020). Covid-19 salgınında ev içi şiddet [Özel Say1]. Adli Tıp Bülteni, 25, 48-57. DOI: 10.17986/blm.2020.v25i.1408.

Falu, A. (2010). Violence and discrimination in cities. A. Falu (Ed.). Women in the city; On violence and rights içinde (ss. 15-39), Women and Habitat Network of Latin America Ediciones SUR.

Fenster, T. (1999). Gender, human rights and planning. London, New York: Routledge.

Fenster, T. (2005). The right to the gendered city: Different formations of belonging in everyday life, Journal of Gender Studies, 14 (3), 217-231. https://doi.org/10.1080/09589230500264109.

G. [@iamayoruk]. (2020, 21 Temmuz). geçen işten gelirken biri takip etti bi markete girip yardım istedim takip edeni parmağımla gösterdim market çalışanı eve kadar bıraktı,rüyamda tecavüze uğruyodum,2 kez sokakta yürürken gölgemden korktum kalbim küt küt attı:( bunları yaşatanların hesap vereceği günler de gelicek. [Tweet]. Erişim adresi: https://twitter.com/iamayoruk/status/1285655934967177220?s=20.

Geniş, Ş. ve Akkirman Köse, D. ( 2020). Eşitsizlik mekânları olarak mahalleler ve kadınların kent hakkı. Amme İdaresi Dergisi, 53 (1), 1-35. 19 Ocak 2021 tarihinde https:/www.researchgate.net/publication/340515201_Esitsizlik_Mekan-

lari_Olarak_Mahalleler_ve_Kadinlarin_Kent_Hakki_Neighborhoods_as_Spaces_of_Inequality_and_Women's_Right_to_the_City adresinden erişildi.

Gius, C. (2020). Women in the lockdown in Europe. Media representations of gender differences in "phase 1" of the coronavirus pandemic. Mediascapes Journal ,16. 10 Ocak 2021 tarihinde https://ojs.uniroma1.it/index.php/mediascapes/article/view/17199/16421 adresinden erişildi.

Hürriyet. (2020, 21 Mart). Bariyerlere bile aldırmadı! Esenyurt'ta şaşırtan görüntüler. 17 Ocak 2021 tarihinde https://www.hurriyet.com.tr/gundem/bariyerlere-bile-aldirmadi-esenyurtta-sasirtan-goruntuler-41474493 adresinden erişildi. 
Hürriyet. (2020, 5 Nisan). Balkondan balkona 'isim-şehir' oynayıp, türkü söylediler. 29 Ocak 2021 tarihinde https:/www.hurriyet.com.tr/video/balkondan-balkona-isimsehir-oynayip-turku-soylediler-41486810 adresinden erişildi.

Hürriyet. (2020, 14 Nisan). Sultangazi 'de hırdavatçı dükkanını kahvehaneye çevirdiler. 17 Ocak 2021 tarihinde https://www.hurriyet.com.tr/gundem/sultangazide-hirdavatci-dukkanini-kahvehaneye-cevirdiler-41494100 adresinden erişildi.

Hürriyet. (2020, 5 Mayıs). Kumar baskınından kaçmak için ă̆aca çıktı. 15 Ocak 2021 tarihinde https://www.hurriyet.com.tr/gundem/kumar-baskininda-yakalanmamak-icin-agaca-cikti-41510248 adresinden erişildi.

Hürriyet. (2020, 7 Mayıs). Pes dedirten olay! Tünel yapmışlar... 17 Ocak 2021 https://www.hurriyet.com.tr/gundem/pes-dedirten-olay-tunel-yapmislar41512148 adresinden erişildi.

Iranmanesh, A. ve Alpar Atun, R. (2020). Reading the changing dynamic of urban social distances during the Covid-19 pandemic via Twitter. European Societies, 23, 872-886. https://doi.org/10.1080/14616696.2020.1846066

İlkkaracan, İ. ve Memiş, E. (2020). Covid-19 küresel salgın sürecinde Türkiye'de bakım ekonomisi ve toplumsal cinsiyet temelli eşitsizlikler. UNDP. 15 Ocak 2021 tarihinde https://www.tr.undp.org/content/turkey/tr/home/library/corporatereports/COVID-gender-survey-report.html adresinden erişildi.

Kadın Cinayetlerini Durduracağız Platformu. (2020). Veriler. 19 Ocak 2021 tarihinde http:// kadincinayetlerinidurduracagiz.net/kategori/veriler adresinden erişildi.

Kaplan, T. (1997). Crazy for democracy: Women in grassroots movements. New York: Routledge.

Karataş, Ş. ve Binark, M. (2016). Yeni medyada yaratıcı kültür: Troller ve ürünleri 'caps'ler", TRT Akademi Dergisi, 1. 14 Ocak 2021 tarihinde https://dergipark.org.tr/tr/download/article-file/218499 adresinden erişildi.

Kelly, L. (1987). The continuum of sexual violence. Hanmer J. ve Maynard M. (Ed.) Violence and social control içinde (ss. 46- 61). London: British Sociological Association.

Kelly, L. (2012). Standing the test of time? Reflections on the concept of the continuum of sexual violence. In J. Brown ve S. Walklate (Ed.), Handbook on sexual violence içinde (ss. xvii- xxvi). London: Routledge.

Kim, Annice E., Hansen, H. M., Joe, M., Richards, A. K., Duke, J. ve Allen, J. A. (2013). Methodological considerations in analyzing twitter data, JNCI Monographs, 47, 140-146. https://doi.org/10.1093/jncimonographs/lgt026

KONDA. (2019). Türkiye'de toplumsal cinsiyet raporu: Hayat tarzları 2018 araştırmast. 14 Ocak $2021 \quad$ tarihinde https://konda.com.tr/wp-content/uploads/2019/11/KONDA_ToplumsalCinsiyetRaporu.pdf adresinden erişildi.

Koskela H. (1997). 'Bold walk and breakings': Women's spatial confidence versus fear of violence. Gender, Place and Culture, 4(3), 301-319. https://doi.org/10.1080/09663699725369 
Kümbetoğlu, B. (2001). Kentsel alan ve yerel yönetimlerde toplumsal cinsiyet. A. İlyasoğlu ve N. Akgökçe (Der.), Yerli bir feminizme doğru içinde (ss.259-282). İstanbul: Sel Yayıncilik.

Lefebvre, H. (1991/1973). The production of space. (D. N. Smith, Çev.). Oxford: Blackwell Publishing.

Listerborn, C. (2016). Feminist struggle over urban safety and the politics of space. European Journal of Women's Studies, 26, 1-14. https://doi.org/10.1177/1350506815616409.

Lisztomania. [@annemderkiii]. (2020, 17 Haziran). Şu an gerçekleşen olayı anlatıyorum, evimden 100 metre ileride olan markete giderken ve dönerken araba ile takip edildim. Kafanıza soksanız iyi olur bunun hiç bir açıklanabilir tarafı yok sizi savunanlara yine de cevap vereyim, açık giyinmemiştim, dar giyinmemiştim, makyaj bile.. [Tweet]. Erişim adresi: https://twitter.com/annemderkiii/status/1273313510152441859?s=20.

Lordoğlu, C. (2016). Kent coğrafyasında kadınların güvenlik endişeleri, Modus Operandl, 4, 151-176.

Lordoğlu, C. (2018). İstanbul'da bekâr kadın olmak. İstanbul: İletişim Yayınları.

Low, S. ve Smart, A. (2020). Thoughts about public space during covid-19 pandemic. City $\mathcal{E}$ Society, 32 (1), 1-5 https://doi.org/10.1111/ciso.12260.

Matruşka. [@matruskagiller]. (2020, 19 Mayıs). İki aydan sonra ilk defa çarşıya çıktım. Toplamda 45 dakika çarşıda kaldım. [Tweet]. Erişim adresi: https://twitter.com/matruskagiller/status/1262769771596177408?s=20.

Mackenzie, S. (1989). Women in the city, R. Peet ve N. Thrift (Der.), New models in geography içinde, Londra: Unwin Hyman.

Massey, D. (1994) Space, Place and Gender, Oxford: Polity Press.

Massey, D. (2009). Concepts of space and power in theory and in political practice. Doc. Anàl. Geogr. 55, 10 Ocak 2021 tarihinde https://ddd.uab.cat/pub/dag/02121573n55/02121573n55p15.pdf adresinden erişildi.

McDowell, L. (1983). Towards an understanding of the gender division of urban space. Environment and Planning D: Society and Space, 1, 59-72. https://doi.org/10.1068/d010059.

Мeлica. [@melloyadamelisa]. (2020, 13 Mayıs). Annemle balkonda oturduk Türk kahvesi iciyoruzzzzz karantinada tek özgürlüğümüz balkon oldu. [Tweet]. Erişim adresi: https://twitter.com/melloyadamelisa/status/1260671191297163264?s=20

Milliyet. (2020, 21 Mart). Bariyerler bile durdurmadı. 17 Ocak 2021 tarihinde https://www.milliyet.com.tr/gundem/bariyerler-bile-durdurmadi-6170876 adresinden erişildi.

Milliyet. (2020, 22 Mart). Esenyurt'ta yasak tanımayan yaşlı vatandaş! 'Evde sıkılıyorum, dışarıya çıktım'. 9 Ocak 2021 tarihinde https://www.milliyet.com.tr/gundem/esenyurtta-yasak-tanimayan-yasli-vatandas-evde-sikiliyorum-disariyaciktim-6171218 adresinden erişildi. 
Milliyet. (2020, 26 Mart). Mersin'de kapatılan hamamı kahvehaneye çevirdiler. 19 Ocak 2021 tarihinde https://www.milliyet.com.tr/milliyet-tv/mersinde-kapatilan-hamami-kahvehaneye-cevirdiler-video-6174909 adresinden erişildi.

Milliyet. (2020, 13 Nisan). Kumar masasında basılınca camdan kaçmaya çalıştı!. 12 Ocak 2021 tarihinde https:/www.milliyet.com.tr/gundem/kumar-masasinda-basilinca-camdan-kacmaya-calisti-6187771 adresinden erişildi.

Mitchell, D. (2003). The right to the city: Social justice and the fight for public space., Londra ve New York: Guildford Press.

Mutlu, B. ve Şafak Dikmen, E. (2020). Neden internet ve yeni medya araştırmalarında araştırma etiği gerekli?. 14 Ocak 2021 tarihinde https://ekitap.alternatifbilisim.org/pdf/yeni-medya-arastirmalarinda-etik-bakis-acisi.pdf adresinden erişildi.

Öcal, T. [@tugba_0cal]. (2020, 24 Mart). Montlarımızı giyip 5 dakika balkonda mola verdik, oradan buradan sohbet ettik. Başka bir yere gidip gelmiş gibi oldum valla. Evde 8. gün. \#EvdeKal [Tweet]. Erişim adresi: https://twitter.com/tugba_0cal/status/1242436985295441920?s=20.

Pain, R. (1991). Space, sexual violence and social control: Integrating geographical and feminist analyses of women's fear of crime. Progress in Human Geography, 15, 415-431. https://doi.org/10.1177/030913259101500403.

Pain, R. (2000). Place, social relations and the fear of crime: A review. Progress in $\mathrm{Hu}$ man Geography, 24, 365-387. https://doi.org/10.1191/030913200701540474

Parvathi, M.S. (2020) The rhetoric of privacy and the gendering of domestic violence in the Covid-19 pandemic. Journal of Comparative Literature and Aesthetics, 44 (1), 10 Ocak 2021 tarihinde http://jcla.in/wp-content/uploads/2021/01/JCLA-44.1Spring-2021_Parvathi-M.S..pdf adresinden erişildi.

Sabah. (2020, 30 Mart ). Koronavirüs nedeniyle pencerelere çıkarak gün yaptılar. 13 Ocak 2021 tarihinde https://www.sabah.com.tr/galeri/yasam/koronavirus-nedeniyle-pencerelere-cikarak-gun-yaptilar adresinden erişildi.

Sadri, H. (2011). Kadınların kent hakkı. TMMOB Mimarlar Odası Ankara Şubesi Bülten, 87, 12 Ocak 2021 tarihinde https://www.researchgate.net/publication/278685054_Kadinlarin_Kent_Hakki adresinden erişildi.

Shaw, M., Andrew, C., Whitzman, C., Klodawsky, F., Viswanath, K. ve Legacy, C. (2012). Introduction: Challenges, opportunities and tools, In C. Whitzman, C. Legacy, C. Andrew, F. Klodawsky, M. Shaw ve K. Viswanath (Ed.). Building inclusive cities: Women's safety and the right to the city, London \& New York: Routledge.

Sosyo Politik Saha Araştırmaları Merkezi. (2020). Covid-19 karantinasından kadının etkilenimi ile kadın ve çocuğa yönelik şiddete ilişkin türkiye araştırma raporu. 11 Ocak 2021 tarihinde https://sahamerkezi.org/covid-19-karantinasindan-kadinin-etkilenimi-ile-kadin-ve-cocuga-yonelik-siddete-iliskin-turkiye-arastirma-raporu/ adresinden erişildi. 
Sözcü. (2020, 19 Mart). Bursa ve Edirne'de corona tedbiri olarak bankları söktüler! 10 Ocak 2021 tarihinde https://www.sozcu.com.tr/2020/gundem/bursa-ve-edirnedecorona-tedbiri-olarak-banklari-soktuler-5689795/ adresinden erişildi.

Sözcü. (2020, 21 Mart). Yaşlıları evde tutamıyoruz: 'Biz şimdi nereye oturacağız?. 13 Ocak 2021 tarihinde https://www.sozcu.com.tr/2020/gundem/yaslilari-evde-tutamiyoruz-biz-simdi-nereye-oturacagiz-5693201/?utm_source=dahafazla_haber\&utm_medium=free\&utm_campaign=dahafazlahaber adresinden erişildi.

T.C. İçişleri Bakanlığı. (2020a). 65 yaş ve üstü ile kronik rahatsızlığı olanlara sokağa çıkma yasağı genelgesi. 11 Ocak 2021 tarihinde https://www.icisleri.gov.tr/65yas-ve-ustu-ile-kronik-rahatsizligi-olanlara-sokaga-cikma-yasagi-genelgesi adresinden erişildi.

T.C. İçişleri Bakanlığı (2020b). Koronavirüs tedbirleri genelgesi kapsamında 149.382 iş yeri geçici süreliğine faaliyetlerine ara verdi. 10 Ocak 2021 tarihinde https://www.icisleri.gov.tr/koronavirus-tedbirleri-genelgesi-kapsaminda149382-is-yeri-gecici-sureligine-faaliyetlerine-ara-verdi adresinden erişildi.

TRT Haber. (2020, 21 Nisan). Türkiye'nin koronavirüse karşı gün gün attığı adımlar. 15 Ocak 2021 tarihinde https://www.trthaber.com/haber/turkiye/turkiyenin-koronaviruse-karsi-gun-gun-attigi-adimlar-477903.html adresinden erişildi.

Tuncer, S. (2018). Women and public space in Turkey: Gender, modernity and the urban experience. London and New York: I.B.Tauris.

Valentine, G. (1989). The geography of women's fear. Area, 21, 385-390. 10 Ocak 2021 tarihinde https://www.jstor.org/stable/20000063 adresinden erişildi.

Valentino-DeVries, J., Lu, D. ve Dance, G.J.X. (2020). Location data says it all: Staying at home during coronavirus is a luxury. The New York Times. 15 Ocak 2021 tarihinde https://www.nytimes.com/interactive/2020/04/03/us/coronavirus-stayhome-rich-poor.html adresinden erişildi.

Van Dorn, A., Cooney, R. ve Sabin, M. (2020). Covid-19 exacerbating inequalities in the US. The Lancet, 395(10232), 1243-1244. https://doi:10.1016/S01406736(20)30893-X.

Vera-Gray, F. ve Kelly, L. (2020): Contested gendered space: Public sexual harassment and women's safety work. International Journal of Comparative and Applied Criminal Justice, 44 (1), 265-275, https://doi.org/10.1080/01924036.2020.1732435

Wilson, E. (1991). The Sphinx and the City. London: Virago.

Yüksel, S. [@SevgiNilsu]. (2020, 2 Nisan). Bende bir sağlık çalışanıyım ve özellikle akşam nöbetine giderken ya da akşam işten çıkarken heryerin karanlık ve 1ssız olmasından dolayı çok tedirginim 2 kere yanımdan geçen arabalar tarafından taciz edildim kendimi koronadan ve tacizden nasil koruyacam bilmiyorum. .\#vaka18135 [Tweet]. Erişim adresi: https://twitter.com/SevgiNilsu/status/1245772177548468231?s=20. 